\title{
Nature of crust in the central Red Sea
}

Neil C. Mitchell ${ }^{1}$ and Yongcheol Park ${ }^{2}$

${ }^{1}$ School of Earth, Atmospheric and Planetary Sciences, University of Manchester, Williamson Building, Oxford Road, Manchester M13 9PL, UK.

${ }^{2}$ Korea Polar Research Institute, 213-3, Songdo-dong, Yeonsu-gu, Incheon 406-840, Republic of Korea

This is a pre-publication version of an article published in the Elsevier journal Tectonophysics: http://dx.doi.org/10.1016/j.tecto.2014.04.029

Keywords: salt tectonics, Red Sea deeps, ocean-continent transition, Thetis Deep, seismic refraction, gravity. 


\begin{abstract}
A transition between continental crust in the northern Red Sea and oceanic crust in the southern Red Sea coincides broadly with a southward increase in plate tectonic separation rate and with a decrease in upper mantle seismic velocity. We re-evaluate here the nature of crust in the intervening central Red Sea with the results of legacy seismic refraction experiments and recently released marine gravity anomalies derived from satellite altimeter measurements. In the refraction data, collected east of Thetis Deep, velocities of 6.6-6.9 $\mathrm{km} \mathrm{s}^{-1}$ of a deep refracting layer, which are similar to measured velocities of unaltered gabbro samples, extend outside the deep to $65 \mathrm{~km}$ from the axis. The new version of the marine gravity field reveals trends crossing the central Red Sea. Whereas some of them connect with major lineaments in the surrounding AfricanArabian shield, those around Thetis Deep die out towards the coastlines. They can be paired across the ridge and lie slightly oblique to plate motions, as is typical of oceanic fracture zones or non-transform discontinuities migrating away from hotspots. Taken together these observations support the view that an oceanic rather than extended continental crust underlies this part of the central Red Sea.

The crestal mountains around the median valleys of slow-spreading ridges are typically 500-1000 m lower at spreading discontinuities. Around Thetis Deep, the similar pattern in the gravity field to those of slow-spreading ridges suggests that the crestal mountains may variably block or impede flowage of evaporites towards the spreading centre, whereas the discontinuities may mark areas where flowage is unobstructed. Limited multibeam data collected in transits outside Thetis Deep show oblique fabrics as expected from these predicted movements.
\end{abstract}




\section{Introduction}

The change in type of crust in the Red Sea from continental in the north (Cochran, 2005; Cochran and Karner, 2007; Gaulier et al., 1986; Gaulier et al., 1988; Martinez and Cochran, 1988) to oceanic in the south (Allan, 1970; Cochran, 1983; Roeser, 1975; Vine, 1966) has been suggested to be a consequence of total extension increasing southwards away from the pole of opening between Arabia and Nubia (Bonatti, 1985; Bosworth et al., 2005), which has lain to the northwest of the Red Sea for at least the last few million years (Chu and Gordon, 1998). According to that view, the northern Red Sea is at an

early stage of development and will proceed to seafloor spreading with further extension (Cochran, 2005). More recently, however, Cochran and Karner (2007) have suggested that the lack of seafloor spreading in the northern Red Sea is instead a result of lower mantle temperature and hence greater lithospheric strength there, which is manifested in larger fault blocks interpreted from seismic, magnetic and gravity data. A stronger lithosphere may have prevented the transition to seafloor spreading.

Large-scale tomographic studies reveal upper-mantle (200 km depth) S- and Pwave seismic velocities increasing by up to a few percentages from south to north in the Red Sea and away from the Afar hotspot (Figure 1), consistent with lower temperatures and hence thicker lithosphere in the north (Begg et al., 2009; Debayle et al., 2001; Pasyanos and Nyblade, 2007; Priestly et al., 2008; Ritsema and van Heijst, 2000; Sicilia et al., 2008). Most of these studies lacked the configuration of seismograph stations necessary to record the structure beneath the Red Sea in detail. However, Park et al. (2007) used teleseismic records from stations within Saudi Arabia distributed across the 
kingdom, along with public Global Seismograph Network station data. Although still not resolving structure beneath all the Red Sea, their model provides a vertical section along the Arabian Red Sea coast, which at depth may mimic that beneath the Red Sea and the variation prior to rifting. Their profile B-B' is reproduced in Figure 1. At $200 \mathrm{~km}$ depth, they resolved a $-1.5 \%$ shear wave velocity $\left(\mathrm{V}_{\mathrm{s}}\right)$ anomaly beneath the coast of the southern Red Sea, increasing to around $-1 \%$ in the central Red Sea (profile distances $700-800 \mathrm{~km}$ ) and to $0 \%$ or more in the northern Red Sea. A somewhat similar structure at $200 \mathrm{~km}$ depth was found by Park et al. (2008) using Rayleigh wave tomography, though with a less clear northward progressive increase in $\mathrm{V}_{\mathrm{s}}$. Combined with $\mathrm{S}$-wave polarisation analysis and SKS splitting results, they interpreted the structure as indicating impact of part of the Afar plume beneath the southern Arabian shield and flow of some of the plume material beneath the rift as far as the central Red Sea. This general pattern is corroborated by geochemical analyses of lavas corrected for shallow fractionation $\left(\mathrm{Na}_{8.0}\right)$, which suggest that upper mantle temperatures generally decline going from $18^{\circ} \mathrm{N}$ to $26^{\circ} \mathrm{N}$ by about $60^{\circ} \mathrm{C}$ (Haase et al., 2000).

A transitional region exists (Figure 1) extending roughly from $19^{\circ} \mathrm{N}$ where the sea floor spreading magnetic anomalies are well defined and confirm oceanic crust (Izzeldin, 1987; Zahran et al., 2003) to $25^{\circ} \mathrm{N}$, beyond which trends in free-air gravity anomalies are oblique and continental fault blocks have been interpreted (Cochran, 2005; Cochran and Karner, 2007). The nature of the crust in this region is important for testing the above ideas but collecting new deep geophysical data has proved to be difficult. However, recent scientific developments make a re-evaluation of existing data in this region now worthwhile. For example, the estimates of gravity anomalies from satellite altimeter data 
have greatly improved (Marks et al., 2013; Sandwell and Smith, 2009). We show that the depths of a crustal seismic refractor of Tramontini and Davies (1969) co-vary somewhat with the gravity anomalies in the central Red Sea. The plan-view pattern in the gravity field therefore mimics the topography of the crust underlying the evaporites. This allows us to interpret the segmented pattern in the gravity field in this area, which is similar to that of segmented slow-spreading ridges (Schouten et al., 1987; Sempere et al., 1990). Laboratory measurements of velocities and knowledge gained by drilling of the seismic layer 2-3 boundary in the Pacific (Carlson, 2001; Carlson, 2010; Gilbert and Salisbury, 2011; Swift et al., 2008) allow a re-evaluation of the seismic refraction velocities (Davies and Tramontini, 1970; Tramontini and Davies, 1969). In combination, these observations lead us to suggest that much of the central Red Sea is indeed probably underlain by oceanic crust as originally claimed (Tramontini and Davies, 1969). The Red Sea has an unusual geomorphology for a spreading centre of deeps (volcanic-floored depressions commonly containing sea-floor spreading magnetic anomalies) with elevated regions ("inter-trough zones") between them floored with evaporites (Bonatti et al., 1984). We extend the discussion to consider the issue of whether flowage is modulated by crustal topography to the extent that the ridge segmentation controls the pattern of deeps and inter-trough zones as originally suggested by Searle and Ross (1975).

\section{Previous work on seismic and magnetic data in the central Red Sea}

The plate tectonic setting is illustrated in the inset of Figure 1, which shows major crustal lineaments of the African-Arabian shield (Camp, 1984; Stoeser and Camp, 1985). These structures represent the structure of the shield before breakup, which we consider 
later in evaluating whether features in the gravity field within the Red Sea are oceanic or continental. According to Stoeser and Camp (1985), the shield is late Proterozoic in age and the major crustal lineaments in the inset of Figure 1 represent ophiolite-bearing suture zones where the shield was assembled from microplates. According to Stern and Johnson (2010), that assembly occurred between 630 and 600 Ma, with major tectonic activity continuing to $550 \mathrm{Ma}$.

Interpretation of the existing marine geophysical data from the transitional region has been controversial. A refractor in seismic data from there with P-wave velocities $\left(\mathrm{V}_{\mathrm{p}}\right)$ a little less than $7 \mathrm{~km} \mathrm{~s}^{-1}$ and typical of gabbro implies that oceanic crust dominates (Davies and Tramontini, 1970; Drake and Girdler, 1964; Egloff et al., 1991; Tramontini and Davies, 1969). Similarly, Izzeldin (1987) interpreted a basement reflector in seismic reflection data south of $21^{\circ} \mathrm{N}$, which showed little change in character off-axis until close to the coasts. Along with other evidence, he favoured a proto-oceanic crust. However, the lack of high-amplitude lineated magnetic anomalies (Vine and Matthews, 1963) has suggested to some researchers that the crust is more likely to be stretched continental there (Bonatti, 1985; Cochran, 1983; Ligi et al., 2012; Ligi et al., 2011). Accordingly, the high velocities may be attributed to mafic or ultramafic shield rocks or widespread intrusions of mafic lithologies during the Neogene (Cochran, 1983). Bonatti et al. (1984) noted the presence of lower continental crust and sub-continental lithosphere outcropping on Zabargad Island (located in the inset of Figure 1), where metagabbros formed at $>900$ $1000 \mathrm{MPa}$ (Bonatti and Seyler, 1987). Such pressures are too high for an oceanic crust and therefore imply a continental origin. Bonatti and Seyler (1987) speculated that this supported a more widespread stretched continental crust. Furthermore, the inter-trough 
zones do not typically show sea-floor spreading magnetic anomalies, leading to their interpretation as extended continental crust (Ligi et al., 2012).

Nevertheless, the magnetic anomalies outside the "deeps" are not completely attenuated; beyond anomalies 2A in parts of an aeromagnetic dataset (Blank, 1977), Izzeldin $(1987 ; 1989)$ was able to interpret ridge-parallel lineaments in the data from more landward areas. LaBrecque and Zitellini (1985) showed through modelling that subdued anomalies could arise from more widely distributed dyke intrusion and more widespread lava flows and sills. They described these areas as "quasi-oceanic" (equivalent to "proto-oceanic" of other authors (Jackson et al., 2000)). Widespread flows have been found at other continental margins where volcanism is associated with rifting (Mutter et al., 1982). Varied extents of such flows could have led to less distinct vertical magnetization boundaries and hence attenuated magnetic anomalies observed above or at sea level. If deep drawdowns of the Red Sea were associated with the evaporite deposition and occurred abruptly, we suggest that the resulting reduced pressure in the upper mantle would have promoted melting and extensive volcanism, as has been proposed for post-glacial Iceland (Jull and McKenzie, 1996; Maclennan et al., 2002; Slater et al., 1998). Searle and Ross (1975) suggested that eruption of lavas beneath the evaporites and other sediments would lead to slower cooling and thus larger grain sizes of magnetic minerals contributing less intense magnetization. Indeed, with halite permeabilities as low as $10^{-21} \mathrm{~m}^{2}$ (Peach, 1991), heat loss by pore-water advection may be impeded if halite were continuous above an intrusion. In contrast, Levi and Riddihough (1986) pointed to examples where intrusive rocks have been found to have significant magnetization, but suggested that hydrothermal alteration can leach remanance-bearing 
iron-titanium oxides in intrusions. The inter-trough zones may therefore lack magnetic anomalies because eruption under the evaporites there leads to intense hydrothermal alteration by trapped fluids. Although scientific drilling has not penetrated to the deeper evaporites in the central Red Sea, the attenuated anomalies off-axis beyond anomaly $2 \mathrm{~A}$ can be speculated to reflect volcanic spreading beneath evaporites, which were extensively deposited from the mid- to late-Miocene (Bosworth et al., 2005; OrszagSperber et al., 1998) and thus also affected by slow cooling or hydrothermal alteration. In contrast, areas where well-defined anomalies are now overlain by evaporites are explainable by flowage of the evaporites over oceanic crust originally formed under water only (Girdler and Whitmarsh, 1974). Although the magnetic anomalies are subdued off-axis in the central Red Sea, therefore, there are several potential explanations for them that would be compatible with forms of sea-floor spreading.

More recently, surveying with multibeam echo-sounders has completed the mapping of the axis from $16.5^{\circ} \mathrm{N}$ to Nereus Deep at $23^{\circ} \mathrm{N}$ (Augustin et al., 2014; Feldens and Mitchell, in press; Mitchell et al., 2010a; Pautot, 1983; van der Zwan et al., 2013). The data confirm that the deeps discussed here are floored with volcanic geomorphological features. Augustin et al. (2014) interpreted those data and the lack of strike-slip teleseismic earthquakes recorded in the transitional region as suggesting that the axis is a continuous oceanic spreading axis, which is merely obscured at inter-trough zones by evaporite flowage. We examine these ideas below in the light of the segmentation apparent in the gravity anomalies.

\section{Datasets}


The multibeam and seismic data and the DSDP drill sites described below are located in Figure 2.

Multibeam bathymetry

Multibeam echo-sounder data collected around Thetis Deep on RV Urania in 2005 (Mitchell et al., 2010a; Ligi et al., 2011, 2012) are shown in shaded-relief form in Figure 3. The data reveal an area of rugged morphology of faults and volcanic features, marking the floor of Thetis Deep. For example, a prominent cone with a collapse pit can be seen in the lower-centre blue area of the map. Elsewhere volcanic ridges aligned with the faults can be observed running northwest-southeast. On either side of the spreading centre, the seabed is smoother and comprises pelagic or hemipelagic sediments. Within the smooth areas, a series of flow-like features can be observed, with downslope-oriented shallow ridges and valleys. These features have rounded fronts where they rest on the volcanic floor of the deep. The features have been interpreted as viscous gravity flows formed where the Miocene evaporites have become laterally unconstrained by rifting (Feldens and Mitchell, in press; Mitchell et al., 2010a). In two sets of isolated lines of multibeam data outside the deep, some oblique fabrics can be observed (arrow pairs marked "Oblique fabrics" in Figure 3). These have been interpreted as originally orthogonal fabrics created by faulting and folding within the evaporites that have been deformed by shear during flowage (Mitchell et al., 2010a).

\section{$\underline{\text { Seismic refraction data }}$}

Seismic refraction profiles were shot along the blue lines in Figure 2 during the 1960s by Tramontini and Davies (1969) using sonobuoys and explosives. Given the 
celestial navigation and dead reckoning used, the positioning is poor; Tramontini and Davies (1969) estimated the position error to be up to a maximum $6 \mathrm{~km}$. However, the source-receiver distances appear to have been well constrained by the recorded travel times of the direct arrival through the water, because the first arrival time - distance graphs typically show clear changes in gradient between two sets of refracted arrivals. The gradients allowed accurate measurements of velocities, yielding an upper layer of mean velocity $\left(\mathrm{V}_{\mathrm{p}}\right) 4.26 \mathrm{~km} \mathrm{~s}^{-1}$ overlying a deeper refracting layer of $6.38-6.92 \mathrm{~km} \mathrm{~s}^{-1}$.

The depths to the crustal refractor at the sonobuoy locations are plotted in Figure $4 \mathrm{~b}$ (solid square symbols) and the velocities of the two layers are shown in Figure 4a. In Figure 4a, small open circles represent velocity values from single refraction lines; for these, there is some ambiguity of interpretation as values could be biased by an unknown dip of the refractor. Larger open circles underlain by plus symbols represent velocities computed by Tramontini and Davies (1969) by combining pairs of refraction lines (dipping-layer estimates for the line pairs highlighted in yellow in Figure 2). These are shown twice for each sonobuoy pair and connected by horizontal dashed lines. Some lines do not perfectly coincide (Figure 2) because of difficulty maintaining position at sea during data acquisition, so they are not properly reversed. Individual dipping layer velocities should be assessed with the original maps.

Tramontini and Davies (1969) reported refractor depths beneath the sonobuoy locations, so Figures 3 and $4 \mathrm{~b}$ shows the refractor depths at the sonobuoy positions. As the average critical angle for these contrasting velocities $\left(4.26\right.$ and $\left.6.64 \mathrm{~km} \mathrm{~s}^{-1}\right)$ is $\sim 40^{\circ}$, the head waves responsible for these depth values should generally have left the refracting interface less than $2 \mathrm{~km}$ from the sonobuoys along the refraction lines. 
Tramontini and Davies (1969) emphasized that these depths are inaccurate, presumably because it is not possible to evaluate whether the refracting interface is planar (scatter of travel times about the linear trends suggests they are indeed non-planar). Nevertheless, these effects introduce an error that should be random, not systematic.

Velocity models were also derived by Egloff et al. (1991) from refraction experiments with ocean bottom seismometers (OBSs) along the lines P1 and PIII adjacent to Suakin Deep in Figure 2. Their PIII model is shown in Figure 5.

\section{Gravity anomalies}

Free-air gravity anomalies were derived from satellite altimeter measurements by Sandwell and Smith (1997). Subsequently, their gravity estimates have improved with re-tracking of radar waveforms, better filtering methods and increasing coverage by successive altimeter missions (Sandwell and Smith, 2009). Ligi et al. (2012) compared the gravity anomalies in version 18 of the satellite-derived field with shipboard gravity measurements in the central Red Sea and showed them to follow faithfully the shipboard data with local differences typically less than $5 \mathrm{mGal}$ and rarely more than $10 \mathrm{mGal}$. Version 18 was also compared against shipboard data of RV Conrad and RRS Shackleton in Mitchell (in press), revealing some patches of systematic error in the satellite-derived field of the northern Red Sea, though not sufficient to obscure finer scale geological structure in the data. More recently, version 21 incorporating Cyrosat, Envisat and Jason1 satellite altimeter data has been released and shows a reduction of incoherent noise of $2.9 \mathrm{~dB}$ at $15 \mathrm{~km}$ wavelengths, as well as a significant decrease in size of feature resolved in the data compared with version 18 (Marks et al., 2013). Figures 6 and 7 show 
examples of version 21. In Figure 6, the data are contoured to allow assessment of values, whereas in Figure 7 they are shown in shaded relief form to highlight trends parallel (Figure 7a) and perpendicular (Figure 7b) to the Red Sea. As shown below, the anomalies are correlated with elevation of a basement refractor so, in an image of gravity anomalies shaded from northerly compass directions, crustal topography (where it is the cause of the gravity variation) should be revealed with the correct sense, i.e., a ridge in gravity is a ridge in the basement, not a trough. Figure $7 \mathrm{c}$ shows a directional second derivative of these data, further highlighting across-rift trends.

Owing to the lack of gravity data on land of comparable resolution, the land areas in Figure 7 were filled with imagery derived from Shuttle Radar Topography Mission elevation data (Becker et al., 2009). Elevations were filtered with a $25 \mathrm{~km}$ cosine-tapered filter (Wessel and Smith, 1991) in order to reduce their resolution towards that of the offshore gravity data (Marks et al., 2013). Those filtered data were then scaled so that the images produced have similar contrast to the gravity data over sea areas.

Structures in the elevation and gravity data need to be interpreted with extreme caution. Ridge and valley topography in shield areas is the result of a long history of tectonics and erosion, whereas offshore gravity variations reflect crustal density and thickness variations as well as topography of the crust-evaporite interface explored below. However, lithologies that are resistant to erosion (crystalline rocks that are only weakly jointed, for example) are also likely to be dense, so some correspondence might be unsurprising. These images are provided merely as a data exploration step - individual structures require more detailed analysis to investigate fully. The reader should also be 
aware that these image-processing steps deliberately enhance trends perpendicular to the directions shown in the Figure 7 panels, effectively filtering out orthogonal trends.

\section{Evaluation of data}

Seismic velocities of the upper layer are everywhere typical of evaporites and extrusive volcanics (Mitchell et al., 2010a; Tramontini and Davies, 1969). Within the deep, the lower layer has a velocity of $6.38 \mathrm{~km} \mathrm{~s}^{-1}$. Outside the deep to $65 \mathrm{~km}$ off-axis, the mean of the four dipping-layer values is $6.8 \mathrm{~km} \mathrm{~s}^{-1}$ and they range only from 6.62 to $6.92 \mathrm{~km} \mathrm{~s}^{-1}$. The two lines near $70 \mathrm{~km}$ have a smaller velocity of $6.1 \mathrm{~km} \mathrm{~s}^{-1}$. In the intertrough zone, the lower layer has a velocity of $6.86 \mathrm{~km} \mathrm{~s}^{-1}$, which is greater than beneath the floor of the deep. Drake and Girdler (1964) also reported results of a reversed refraction experiment carried out in 1959 along the dashed line in Figure 6a (on the north side of the large ellipse shown). They reported a lower layer velocity of $6.97 \mathrm{~km} \mathrm{~s}^{-1}$ and similar upper-layer velocities to those of Tramontini and Davies (1969).

Tramontini and Davies (1969) suggested that the 6.62-6.92 $\mathrm{km} \mathrm{s}^{-1}$ lower layer velocities outside the deep were compatible with gabbro or a hard limestone. They considered an extensive limestone layer beneath this part of the Red Sea to be unlikely because such lithologies do not dominate the African-Arabian shield rocks on the adjacent land either side of this area. This inference is confirmed by more recent maps (Camp, 1984; Klitzsch et al., 1987; Stoeser and Camp, 1985). They also noted that scatter of the lower refractor travel times did not increase with range, suggesting that heterogeneity was due to topography of the refracting surface, not varied velocity of the lower layer, such as might arise from lithologic heterogeneity. 
A deep seismic refraction experiment was carried out in 1978 by the U.S. Geological Survey along a line extending NNE across the Arabian shield (roughly 400 $\mathrm{km}$ east of Jeddah). Analysis of the recorded seismic arrival times suggested lower crustal velocities of up to $\sim 7 \mathrm{~km} \mathrm{~s}^{-1}$ (Mechie and Prodehl, 1988; Milkereit and Fluh, 1985; Prodehl, 1985), a value overlapping the refractor velocities of Tramontini and Davies (1969). These are typical of lower shield crustal $V_{p}$ compiled by Rudnick and Fountain (1995), who reported a mean and standard deviation of $7.0 \pm 0.3 \mathrm{~km} / \mathrm{s}$. Compositions of xenoliths present in Cenozoic volcanic fields of western Saudi Arabia suggest that the high velocities of the lower crust probably correspond with mafic lithologies (Stern and Johnson, 2010).

However, the data of Prodehl (1985) show significant lateral heterogeneity (unlike the four dipping-layer values from 10-65 km in Figure 4a) and their velocity-depth graphs show decreasing velocities towards the surface. That decrease is most likely partly caused by crack opening with decreasing confining stress affecting elastic moduli. If lower-crustal rocks of the shield were elevated tectonically from pressures of $1000 \mathrm{MPa}$ to $<100 \mathrm{MPa}$, their seismic velocities should decrease by $>0.5 \mathrm{~km} \mathrm{~s}^{-1}$ (Wepfer and Christensen, 1991) and become more heterogeneous with differing lithological responses to pressure release and tectonic fracturing. Therefore, a continental lower-crustal origin for the refractor velocities of Tramontini and Davies (1969) seems unlikely.

The lower-layer velocities overlap with those of serpentinized peridotite as shown by the small solid diamond symbols in Figure 4a derived from laboratory measurements on samples at $200 \mathrm{MPa}$ (Carlson and Miller, 1997; Christensen, 1972; Christensen, 1982). (A confining pressure of $200 \mathrm{MPa}$ is high compared with only $50 \mathrm{MPa}$ expected 
in situ below $\sim 2 \mathrm{~km}$ of evaporite, but most of the velocity change from crack closure typically occurs in the first $100 \mathrm{MPa}$ (Wepfer and Christensen, 1991) and the remaining over-compensated effect of confining pressure makes the laboratory values probably over-estimated by $\sim 0.5 \mathrm{~km} \mathrm{~s}^{-1}$ compared with those expected in situ.) Peridotites outcropping on Zabargad Island (Figure 1 inset for location) represent a sample of the Red Sea basement (Bonatti et al., 1983), prompting speculation that they could be more widespread. However, serpentinite velocities are likely to vary spatially with varied degrees of hydration (represented by the spread of the serpentinite velocities in the right of Figure 4a). For comparison, seismic refraction experiments were carried out over a region of exhumed mantle west of Iberia where scientific drilling has confirmed the presence of serpentinite (Whitmarsh and Wallace, 2001). Velocity-depth graphs derived from the refraction data vary laterally and show a gradual increase with depth towards mantle velocities of $8 \mathrm{~km} \mathrm{~s}^{-1}$ (Chian et al., 1999; Dean et al., 2000; Discovery 215 Working Group, 1998; Whitmarsh et al., 1996). In contrast, although some of their plots do not rule out gradual velocity variations in places, most of the travel time plots shown by Tramontini and Davies (1969) are relatively simple with two branches suggesting two layers rather than a gradient.

The lower refracting layer velocities correspond well with the distribution shown in Figure $4 \mathrm{a}$ of $\mathrm{V}_{\mathrm{p}}$ values of unaltered samples of gabbro considering the possible $0.5 \mathrm{~km}$ $\mathrm{s}^{-1}$ bias due to fractures mentioned earlier. The depths of the lower layer (Figure $4 \mathrm{~b}$ ) are rather shallow for the top of layer 3 of oceanic crust (Mutter and Mutter, 1993), considering that seismic reflection data suggest that around 2 s (two-way time) of the upper layer outside the deep is likely to be evaporite here (Ligi et al., 2012). In 
particular, the two refraction experiments in the floor of Thetis Deep (where igneous morphologies are consistent with the presence of oceanic upper crust) suggest depths to the refractor of only $1.3 \mathrm{~km}$ below seafloor. The refractor depth can also be compared against the trend of mid-ocean ridge axial magma chamber depths (Purdy et al., 1992) towards slow-spreading rates, because such chambers are the precursors of gabbro. For the local spreading rate of $12 \mathrm{~mm} \mathrm{yr}^{-1}$ (Chu and Gordon, 1998), extrapolating the trend would suggest that gabbro should be emplaced at many kilometres depth below the seafloor. Even a shallow magma chamber depth of $2.5 \mathrm{~km}$ below seafloor found in data from the southerly Reykjanes Ridge (Sinha et al., 1997) is deeper than the Thetis area refractor. Nevertheless, a global compilation of thickness of layer 2 by Mutter and Mutter (1993) shows some values smaller than $1.5 \mathrm{~km}$.

Seismic experiments carried out over scientific drilling sites 504B and 1256D in the east Pacific help to understand the nature of the refractor. Carlson (2010) showed velocities from downhole sonic $\left(\mathrm{V}_{\mathrm{p}}\right) \operatorname{logs}$ increasing with depth to $>6.5 \mathrm{~km} \mathrm{~s}^{-1}$ at 1700 metres below seafloor (mbsf) and 1400 mbsf at drilling sites 1256D and 504B, respectively, associated with declining porosity with increasing confining pressure within the dyke section. As $\sim 250 \mathrm{~m}$ of pelagic sediments overlie the top of igneous basement at both sites, the transitions of Carlson (2010) lie at 1450 and $1150 \mathrm{~m}$ within basement for 1256D and 504B, respectively. A compilation of seismic refraction and borehole vertical seismic profiling results by Swift et al. (2008) suggest similar transition depths to $6.5 \mathrm{~km}$ $\mathrm{s}^{-1}$. It seems likely that the refractor interpreted by Tramontini and Davies (1969) represents a transition with depth to low porosities within the dykes rather than the gabbro/dyke transition itself. 
This is further suggested by comparing the refractor depths in the Nereus-Thetis inter-trough zone with interpreted depth to igneous basement from a seismic reflection line of Izzeldin (1989) shown in Figure 8. Izzeldin (1989) interpreted a multi-reflector event contrasting with relatively transparent lower evaporite (which he interpreted as nearly pure halite) as the top of oceanic crust. The refractor depth at the location of the reflection line is presumed to lie between the two recorded refractor depths (heavy grey dashed line in Figure 8). The depth-converted basement reflector depths are a bit less than $1 \mathrm{~km}$ shallower than this average of the refractor depths, as might be expected if crack closure from the weight of evaporite has raised the velocity transition above the 1150-1450 m basement levels found by Carlson (2010) to be producing the refractor.

\section{Basement topography}

\section{Refractor depths}

No refractor representing the top of basement was recorded by Tramontini and Davies (1969), because the seismic velocity of evaporites overlaps with velocities of volcanic extrusive rocks. Nevertheless, to the extent that the refractor that they did record represents a horizon of lowered porosity, probably within the dyke layer (Carlson, 2010), the relief of the refractor should mimic that of the top of igneous basement. Confining pressure will also increase with the evaporite overburden, suggesting a tendency for thicker evaporites over basement depressions to raise the refractor elevation and for the refractor to become elevated off-axis relative to the top of basement. The fact that significant topography of this refractor remains (Figure 4b), however, suggests that confining pressure cannot be the dominating influence on $\mathrm{V}_{\mathrm{p}}$ here. 
The refractor deepens at 20-40 $\mathrm{km}$ away from the rift axis before shoaling again farther away (Figure 4b). The spatial pattern is revealed further in Figure 3. In that map, the refractor lies at 3.3-3.7 km depth within the floor of the deep. In a large region northeast of evaporite flow ' $b$ ' and north of flow 'a' in Figure 3, the refractor is depressed to 4.6-5.3 km. East of flow 'a', the data suggest, going away from the deep, a depression of $4.8 \mathrm{~km}$ depth, a high of $3.4 \mathrm{~km}$ and a further depression of $4.2-5.3 \mathrm{~km}$. The intertrough zone to the northwest is underlain by a deep refractor at 4.2-5.9 $\mathrm{km}$ depth.

In Figure 6, the refraction lines (white) are overlain on the gravity anomalies. As the bathymetry is subdued outside the deeps in the direction parallel with the coasts (Figure 1), coast-parallel gravity variations are most likely to represent variations in density and thickness of the crust and basement topography. The data show a gravity high ("H" in Figure 6) at the same location where the seismic data suggest an elevated refractor. The deep refractor in the inter-trough zone is accompanied by a negative gravity anomaly. The "Off-axis low" marked in Figure 3 corresponds with a general gravity low in Figure 6. Two cross-axis trends of gravity lows are highlighted by the white arrows in Figure 6.

A further test of correspondence can be obtained with the slab formula, whereby the anomaly caused by a layer of infinite lateral extent and constant thickness $h$ and density contrast $\Delta \rho$ is:

$$
\delta g=2 \pi G \Delta \rho h(1)
$$

where $G$ is the gravitational constant. Variations in depth to the refractor (assumed to follow top of basement) can be assessed to see if they would produce the observed variations in the gravity field. To compare the refraction data with the gravity, the free- 
air anomalies in Figure 6 were sampled at the buoy locations. A small position adjustment of $h \cdot \tan \left(\Theta_{c}\right)$, where $\Theta_{c}$ is the seismic critical angle and $h$ is the upper layer thickness, was made to each buoy location along the associated refraction line to allow for where head waves are likely to have left the refracting layer (this correction was small, everywhere less than $4.5 \mathrm{~km}$ ). The sampled gravity anomalies are shown along with the refractor depths in Figure 9a. Despite the scatter in the graphs, the mean (unsigned) deviation of the data from the regression line for the 40-60 km group is only $6.8 \mathrm{mGal}$, a value not much different from deviations of the satellite-derived data from shipboard gravity measurements in the central Red Sea (Ligi et al., 2012; Mitchell, in press) suggesting that a significant component of the scatter may simply be gravity anomaly uncertainty.

The regressions imply effective density contrasts of 0.055 and $0.235 \mathrm{~g} \mathrm{~cm}^{-3}$ for the $>60 \mathrm{~km}$ and 40-60 km data, respectively, if topography of only a single layer were responsible. These contrasts can be compared with those of lithologies expected here. Allowing for equal proportions of halite and anhydrite and using density measurements of Manheim et al. (1974) on the DSDP Leg 23 cores, the evaporite bulk density is probably $\sim 2.5 \mathrm{~g} \mathrm{~cm}^{-3}$ where it is layered. More massive appearance of evaporite in deeper seismic data may indicate more nearly pure halite (Izzeldin, 1987), suggesting alternatively a density of $2.16 \mathrm{~g} \mathrm{~cm}^{-3}$ (Manheim et al., 1974). The $0.235 \mathrm{~g} \mathrm{~cm}^{-3}$ apparent density contrast found in the field data seems modest considering that gabbro, the lithology dominating oceanic crust, has a density of around $3.0 \mathrm{~g} \mathrm{~cm}^{-3}$ (Telford et al., 1976), implying density contrasts of between $0.5 \mathrm{~g} \mathrm{~cm}^{-3}$ (layered evaporite contrasting with gabbro) and $0.86 \mathrm{~g} \mathrm{~cm}^{-3}$ (massive halite contrasting with gabbro). 
In Figure 9b, free-air anomalies were corrected for the density effect of the seabed, using equation (1) with a density contrast of $1.5 \mathrm{~g} \mathrm{~cm}^{-3}$ based on evaporites with equal proportions of halite and anhydrite (bulk density of $2.5 \mathrm{~g} \mathrm{~cm}^{-3}$ ) and water density of $1.0 \mathrm{~g} \mathrm{~cm}^{-3}$. In locations where volcanic lithologies outcrop, a $1.5 \mathrm{~g} \mathrm{~cm}^{-3}$ contrast may be too great because inversion of seabed gravity data from elsewhere suggests extrusive densities of 2.3-2.4 $\mathrm{g} \mathrm{cm}^{-3}$ (Hammer et al., 1991; Hildebrand et al., 1990). It may also be too great where the substrate locally comprises deep pelagic sediments. In Figure 9b, however, the correlation between the gravity anomalies and reflector depths is not improved by this exercise (mean deviation from the regression line is $7.4 \mathrm{mGal}$ for the 40-60 km graph). The effective density contrasts implied by the regression lines for the $40-60 \mathrm{~km}$ and $>60 \mathrm{~km}$ data are 0.222 and $0.070 \mathrm{~g} \mathrm{~cm}^{-3}$, respectively. Partly because the seabed relief is low, it seems the seabed density contrast is not so important for the gravity trends here.

A further gravitational effect arises from the topography of the Moho. Lin et al. (1990) estimated that $\sim 10-20 \mathrm{mGal}$ variation (peak-peak) in gravity anomaly along the Mid-Atlantic Ridge between segment centres and adjacent ridge discontinuities is caused by crustal thickness variations. As the oceanic crust is typically thinner at discontinuities (where the refractor in the Tramontini and Davies (1969) dataset is deeper), the elevated Moho may increase the gravity anomalies by $10-20 \mathrm{mGal}$. This effect would partly reduce the gradient between gravity anomaly and basement depth, potentially explaining why the trends in Figure 9 for 40-60 km are modest. Furthermore, crustal thickness variations and basement topography are likely not perfectly aligned spatially, helping to explain the scatter in these graphs. 
Telford et al. (1976) listed densities of 2.5-2.8 and average $2.64 \mathrm{~g} \mathrm{~cm}^{-3}$ for granite, a typical continental crustal rock. If the basement were average granitic density, density differences of $\sim 0.14$ and $0.48 \mathrm{~g} \mathrm{~cm}^{-3}$ can be expected with evaporite and halite of 2.5 and $2.16 \mathrm{~g} \mathrm{~cm}^{-3}$, respectively. Also given the scatter of the data in Figure 9, a granitic continental crust cannot be ruled out by this regression analysis. According to W. Bosworth (pers. comm., 2013), in the outcropping basement along the Sudanese coast nearest to the seismic experiments "syenites and granites only make up a bit more than $50 \%$ of the exposed section. Basic intrusives and Neoproterozoic schists make up the bulk of the rest." Therefore, a basement average density (Telford et al., 1976) between 2.64 (schist) and $3.03 \mathrm{~g} \mathrm{~cm}^{-3}$ (gabbro) is possible. Nevertheless, the shallower trends in the $>60 \mathrm{~km}$ data relative to the $40-60 \mathrm{~km}$ data are as expected for a transition towards lower density continental crust near to the coast (Izzeldin, 1987). Furthermore, the correlations in Figure 9 for 40-60 km imply that variations in the gravity field reflect topography of basement underlying the evaporites, justifying the following exploration of spatial patterns in the gravity data.

\section{Axial depth compared with lava geochemical data}

Axial depths of mid-ocean ridges vary systematically, tending to be shallower near hotspots, and to vary with fractionation-corrected $\mathrm{Na}_{2} \mathrm{O}$ contents of lavas representing the extent of upper mantle melting ("Na ${ }_{8.0}$ "; Klein and Langmuir (1987)). The axial depth in the Red Sea was sampled from the bathymetry data (Becker et al., 2009) and is shown in Figure 10b. Aside from a deep segment of the axis at $19.6^{\circ} \mathrm{N}$ (Suakin Deep) and a shallow segment at $22^{\circ}-23^{\circ} \mathrm{N}$ (Thetis Deep), the axis generally 
deepens going northwards (bearing in mind that many of the elevated sections north of Suakin Deep are evaporite-floored inter-trough zones (Augustin et al., 2014)). The $\mathrm{Na}_{8.0}$ values shown in Figure 10a (from Haase et al. (2000) and Ligi et al. (2012)) also vary systematically with latitude. Combining the dashed regression line in Figure 10a with a regression computed from the global dataset of ridge axis $\mathrm{Na}_{8.0}$ and axial depth in Klein and Langmuir (1987, their figure 2a), the axial depth variation predicted from the geochemistry is as shown by the dashed line in Figure 10b. It declines by almost $1 \mathrm{~km}$ along the length of the profile, coinciding within $500 \mathrm{~m}$ with the deeps aside from the anomalous regions mentioned.

Spreading ridge segmentation pattern in the gravity anomalies

Izzeldin $(1987 ; 1989)$ observed that the spatial pattern in shipboard gravity data within the central Red Sea is similar to that of spreading ridges. The satellite-derived gravity data in Figures 6 and $7 \mathrm{~b}$ also reveal a typical ridge segmentation pattern over $20^{\circ}$ $23^{\circ} \mathrm{N}$ in the central Red Sea. Figure 11 is an interpretation of ridges and troughs in the combined gravity and elevation data (Figures 7a-7c), with the blue lines around the central trough marking these suggested spreading lineaments (highlighted by the large ellipse). A global compilation of segmentation length-scales in the marine gravity field (Sandwell and Smith, 2009) shows spacings of 50-100 km for spreading rates around 12 $\mathrm{mm} \mathrm{yr}^{-1}$, compatible with the $47 \mathrm{~km}$ mean spacing of lineaments in Figure 11. Briais and Rabinowicz (2002) found a similar mean segment spacing of $52.5 \mathrm{~km}$ for ridges spreading below $40 \mathrm{~mm} \mathrm{yr}^{-1}$ half rate. Furthermore, the gravity anomalies vary across the lineaments in Figure 6 by about $40 \mathrm{mGal}$. This compares with almost double the 
variation along the crestal mountains of the Mid-Atlantic Ridge (Lin et al., 1990), as expected given the greater density contrast of the oceanic crust with water on the MidAtlantic Ridge compared with crust with evaporites in the Red Sea.

In Figure $7 b$, the segmentation of the gravity field in the central Red Sea contrasts with the field south of $20^{\circ} \mathrm{N}$, where along-axis segmentation is absent. The transition from segmented to un-segmented crust going towards the Afar hotspot is similar to that observed on the flanks of the southern Reykjanes Ridge at $58^{\circ} \mathrm{N}$ going northwards towards the Icelandic plume (Sandwell and Smith, 1997; Sandwell and Smith, 2009). The pattern is also different from that in the northern Red Sea, where the dominant fabric has been interpreted to arise from the northwest-southeast oriented continental normal faults (Cochran, 2005).

The plate motion vectors in Figure 1 (inset) were computed from the rotation pole of Chu and Gordon (1998), which coincides (within uncertainties) with those derived from GPS data (ArRajehi et al., 2010; McClusky et al., 2003). Within the central Red Sea around Thetis Deep on the Arabian side, the off-axis discontinuities in Figure 7 are oriented a few degrees clockwise of these predicted plate spreading directions. On the African side, they are a few degrees counter-clockwise. This is as expected for midocean ridge segmentation with small offsets of the ridge axis, because non-transform discontinuities typically migrate along-axis away from hotspots (Briais and Rabinowicz, 2002; Schouten et al., 1987) as apparently occurs here, with migrations away from the Afar hotspot.

A selection of lineaments apparently aligned either side of the coastline between the gravity and elevation datasets are highlighted with dark red circles in Figure 7c. 
Some of these correspond with known continental structures, for example, the northernmost circle encompasses faults of the Qazaz shear zone (Stern and Johnson, 2010), which runs ESE to WNW here. Rifting has been suggested to have initiated along N060 ${ }^{\circ}$ perpendicular to the general trend of the Red Sea, changing in the Miocene to the presently more oblique opening with the development of the Dead Sea transform at 17-18 Ma (Garfunkel and Beyth, 2006) or $14 \mathrm{Ma}$ (Bosworth et al., 2005). Many of the nearcoastal trends in the gravity field lie oblique (a, b, c, d in Figure 11), a common feature of transfer faults in continental margin rift settings where oblique orientations suggest they are re-activated pre-existing faults (Bellahsen et al., 2013). The appearance of these structures demonstrates that the gravity field is well mapped to the coastline, so the absence of the axial segmentation reaching the coast further suggests that the segmentation has an oceanic origin, developing along with development of the spreading centres. Notably, the geometrical relationship between oblique margin structures 'a' and 'd' (Figure 11) and the adjacent offshore oceanic lineaments is similar to that of "Type 1$T^{\prime \prime}$ oceanic fracture zones inherited from oblique synrift transfer fault zones of Bellahsen et al. (2013) (blue lines in Figure 11 are ridges so the fracture zones lie between them, corresponding with offsets of the axial red line). Based on the work in the Gulf of Aden (Bellahsen et al., 2013), the distribution of oceanic spreading cells may have been influenced by the shield structures even though a geometrical relationship is not apparent in the gravity data.

To the north of $23^{\circ} \mathrm{N}$, some lineaments are oblique to both the spreading direction and to normals to that direction, in particular, near Zabargad Island. One such lineament, a large-amplitude gravity feature trends ESE-WNW adjacent to Zabargad Island in Figure 
7a, oblique to the expected modern spreading ridge trend. On the island itself, younger faults are high-angle and oriented north-south (Bosworth et al., 1996; Marshak et al., 1992) and have been interpreted as having formed as part of a transfer zone between offset rift basins north and south of the island (Marshak et al., 1992). However, the ESEWNW gravity feature is also curiously oblique to the NW-SE rift basin trends expected (Marshak et al., 1992) so the origin of this feature remains enigmatic.

\section{Discussion}

Nature of crust

The crust is more likely to be oceanic than continental south of the Halaib-Yanbu suture $\left(\sim 23.5^{\circ} \mathrm{N}\right)$ based on the above reasoning. A transition in style of accretion occurs farther south from segmented oceanic crust typical of slow-spreading ridges in the central Red Sea to an unsegmented, smooth type typical of faster spreading and/or ridges overlying mantle of elevated temperature (e.g., Reykjanes Ridge) in the south. Between the Halaib-Yanbu suture and the northern Red Sea region studied by Cochran and coworkers (Cochran, 2005; Cochran and Karner, 2007; Martinez and Cochran, 1988), the nature of the crust is confused so that the transition cannot be assessed accurately at present. Nevertheless, there is a general change from continental rifting in the north (Cochran and Karner, 2007) to oceanic in the centre and south, which broadly reflects the increasing mantle velocity structure (Figure 1) and plate-tectonic extension rate going south.

In Figure 1, S-wave seismic velocity anomaly varies from around $-1.5 \%$ in the southern Red Sea coast to $+0.5 \%$ in the northern Red Sea, and reaches around $-1 \%$ in the 
central Red Sea north of Jeddah. Park et al. (2007) estimated temperature anomalies using a rate of $1.2 \mathrm{~m} \mathrm{~s}^{-1} \mathrm{~K}^{-1}$ from data in Faul and Jackson (2005). Thus, the $2 \%$ or $87 \mathrm{~m}$ $\mathrm{s}^{-1}$ variation in $\mathrm{V}_{\mathrm{s}}$ implies around $72^{\circ}$ of temperature decrease going south to north in the Red Sea. This compares favourably with the $60^{\circ}$ change from $18^{\circ} \mathrm{N}$ to $26^{\circ} \mathrm{N}$ inferred from $\mathrm{Na}_{2} \mathrm{O}$ concentrations of lava samples corrected for low-pressure fractionation to 8 wt\% MgO ("Na ${ }_{8.0} "$; Haase et al. (2000)). The temperature change is accompanied by declining rate of separation between Nubia and Arabia of 15 to $9 \mathrm{~mm}^{-e^{-1}}$, a decrease of $40 \%$. This implies a slower rise of the mantle beneath the rift, allowing greater conductive cooling in the north. The two trends combined probably lead to significantly thicker lithosphere in the north.

\section{Consequences for evaporite flowage}

Searle and Ross (1975) suggested that the topography of oceanic crust beneath the evaporites may be modulating flowage, such that flowage is greater at oceanic spreading segment ends where the crust is typically deeper and less able to block the flow. If correct, the presence of continuous evaporite at inter-trough zones may reflect greater flowage in these areas.

Oblique fabrics are potentially interpretable as produced by shear within the evaporites (Mitchell et al., 2010a). The multibeam data in Figure 3 outside the deep suggest at least two zones of shear (double-headed arrows), one along the southerly offaxis extension of the inter-trough zone $\left(22^{\circ} 52^{\prime} \mathrm{N}\right)$ and the other on the southerly limit of flow-like feature 'a'. The total flooring of the axis by evaporites in the inter-trough zone is accompanied by a deeper refractor (Tramontini and Davies, 1969). The coincident 
seismic reflection data summarized in Figure 8 show no obvious impediment to flowage there and the gravity low extending off-axis (Figure 6) suggests the trace of a ridge-axis discontinuity (Izzeldin, 1989) implying an extended depression. The data from Thetis Deep are therefore locally consistent with the idea of Searle and Ross (1975).

To explore this idea more generally, the evaporite elevation above the igneous crust of the deeps was constructed, indicating the potential energy available for flowage towards the deep and highlighting areas where flowage has not overwhelmed axial depressions. Two off-axis profiles (irregular dotted and dashed lines) were sampled from the bathymetry as marked in Figure 12 and are shown in Figure 10b. The evaporite surface lies approximately $0.2 \mathrm{~s}$ TWT or around $200 \mathrm{~m}$ depth below seafloor, beneath the surface hemipelagic sediments (Ross and Schlee, 1973). Because the evaporite surface outside the deeps also deepens northwards, the elevation of evaporite above igneous crust does not increase as much as would be expected otherwise, but nevertheless there is an increase in that elevation northwards. The diamond symbols in Figure 10b represent locations where across-axis gravity lows intersect the spreading axis (Figure 7c and 11). These should correspond with spreading discontinuities, where the evaporites are expected to have flown farther (Searle and Ross, 1975). Although not all highs in the along-axis depth profile correspond with these gravity lows, the majority apparently do (note that the peak at $22^{\circ} 15^{\prime} \mathrm{N}$ is not an inter-trough zone (Ligi et al., 2012)).

A seismic reflection profile crossing Nereus Deep (Izzeldin, 1987) suggests that flowage is fully blocked by igneous basement at that profile location. As mentioned, multibeam sonar and seismic refraction data suggest variably blocked flowage at Thetis Deep (Mitchell et al., 2010a; Mitchell et al., 2010b). On the other hand, Izzeldin (1987, 
his Fig. 6) showed interpretations of seven seismic profiles crossing the spreading axis from $19^{\circ} \mathrm{N}$ to nearly $21^{\circ} \mathrm{N}$, which suggest that the evaporites are unimpeded over those latitudes, in particular, the unfilled depression at Suakin Deep is not obviously explained by blockage in his interpretations. However, the seismic refraction results in Figure 5 contradict that view. This issue would benefit from a more complete coverage of seismic reflection data to evaluate further but the existing seismic data do not obviously show basement configuration as being the sole effect on flowage.

Other factors affecting strain rates in evaporites include the bulk composition (halite being generally weaker than other evaporite minerals), grain size, pore water content (of which only small quantities can substantially weaken halite by pressure solution creep (Urai et al., 1986)) and temperature. Izzeldin (1987) discriminated transparent facies in his seismic data (presumably halite) from more laminated facies (presumably layered evaporites such as those recovered at the DSDP sites (Whitmarsh et al., 1974)) but it is difficult to infer a regional variation capable of explaining the varied geomorphology.

Concerning evaporite temperatures, Bonatti et al. (1984) summarized heat flow data in the region $22^{\circ} \mathrm{N}$ to $26^{\circ} \mathrm{N}$ of typically $100-200 \mathrm{~mW} \mathrm{~m}$ outside the deeps and rising above $1000 \mathrm{~mW} \mathrm{~m} \mathrm{~m}^{-2}$ within the deeps. Assuming conductive heat flow through halite of $5 \mathrm{~W} \mathrm{~m}^{-1} \mathrm{~K}^{-1}$ (Wheildon et al., 1974), the former rates imply temperatures of $20^{\circ}-40^{\circ} \mathrm{K}$ above bottom water temperatures at $1000 \mathrm{~m}$ depth. Experimental data and theoretical arguments suggest that a $50^{\circ} \mathrm{K}$ difference should lead to around half an order of magnitude variation in halite strain rate due to pressure solution creep (Spiers et al., 1990 ) or around a factor of three. The $20^{\circ} \mathrm{K}$ variation should therefore lead to a strain 
rate variation of less than a factor of two approximately. Other heat flow measurements extending farther south to below $18^{\circ} \mathrm{N}$ (Makris et al., 1991), however, suggest a more substantial variability across and along the Red Sea, though without obviously correlating with the axial morphology. In summary, the factors modulating evaporite flowage are unclear regionally, although locally around Thetis Deep the basement configuration appears to be important.

\section{Magnetic anomalies}

We re-consider here the arguments surrounding the magnetic anomalies introduced earlier. Izzeldin (1987) showed an aeromagnetic dataset extending off-axis and revealing anomalies aligned parallel to the spreading axis. Figure 13 shows magnetic anomaly data (red lines) and free-air gravity data (blue lines) collected on RRS Shackleton in 1979 (Girdler and Southren, 1987) along lines A-J located in Figure 12, which are roughly parallel to the present spreading direction. If the gravity minimum near the centre of each profile is taken to be the spreading axis (interpretations marked with vertical bars in Figure 13), the magnetic anomalies there are the axial anomalies and can be observed to be complex, consistent with three-dimensional basement magnetization structures (Searle and Ross, 1975). Whereas some pairing of anomalies on opposite flanks might be possible (e.g., in profile A), generally this is not the case.

The profiles in Figure 13 illustrate the lower amplitudes of anomalies away from the axis compared with those on-axis, which is also revealed in scatter plots derived from all the ship-board anomalies with water depth in Figure 14. Ligi et al. (2012) inverted a map of magnetic anomalies for magnetization intensity in Thetis Deep. The axial high 
magnetizations in their results correspond well to the extent of volcanic geomorphology, abruptly decreasing at the edges of the evaporites. Therefore, in an attempt to see if there is any relationship of low amplitudes with the extent of evaporite (for example, if caused by high-temperature alteration (Levi and Riddihough, 1986)), Figure 12 shows in bold red and blue where the anomalies are greater than $300 \mathrm{nT}$ or less than $-300 \mathrm{nT}$, respectively (300 $\mathrm{nT}$ is an arbitrary level found to discriminate on and off-axis anomalies). As also illustrated by Figure 14, high amplitudes generally extend only a small distance outside the deeps and are absent in the inter-trough zones. Green circles in Figure 12 show interpreted limits to these anomalies. Their separations resolved parallel to the spreading direction and divided by the local spreading velocity (Chu and Gordon, 1998) are around 1-3 Ma. The decline in amplitude unfortunately occurs at an age that is comparable to that of the reduction in basalt magnetizations by alteration at the ocean floor; magnetizations decrease by a factor of nearly four in only 5 m.y. (Bleil and Peterson, 1983). It is therefore difficult to resolve a separate evaporite-induced reduction.

\section{South Atlantic basins}

Evaporites were deposited in the early stages of opening of other ocean basins (Emery and Uchupi, 1984; Evans, 1978; Rona, 1982), so it is tempting to speculate on the potential for flowage in those areas also. The original configuration of the deposits relative to the basement is often difficult to work out for such areas because the structure is commonly obscured in seismic data by thick marginal sediments and mobilisation of the evaporites, and because information from drilling, if available, remains unreported. However, high quality regional 2D seismic data interpreted by Davison et al. (2012) 
suggest that there has been varied flowage of evaporites over an outer high bounding the seaward extents of the Brazilian Campos and Santos offshore basins. Bouguer gravity anomaly maps of that region (Karner and Gambôa (2007) show anomalies at and beyond the outer high varying by $>20 \mathrm{mGal}$ parallel to the margin and some (though more subdued) variability in similar maps of the corresponding west African margin. Three lines of combined refraction and reflection seismic data on the Angola margin appear to show somewhat reduced extent of evaporites where there is an outer high at the seaward margin of transitional crust (Contrucci et al., 2004; Moulin et al., 2005). More investigation is needed but there appears to have been the potential for some topographically modulated flowage to have occurred in the early South Atlantic basins.

\section{Conclusions}

Comparisons with laboratory and field measurements of seismic velocity elsewhere, along with the consistency of the $\sim 6.9 \mathrm{~km} \mathrm{~s}^{-1}$ lower refractor of Tramontini and Davies (1969), suggest that the crust in the central Red Sea around Thetis Deep has a mafic lithology and, on balance, is probably oceanic. The precise refracting horizon may lie within the dyke layer rather than top of gabbros owing to effects of confining stress on seismic velocities (Carlson, 2010). Other explanations for the lower refractor are considered less likely.

Increasing refractor depths correspond generally with decreasing free air gravity anomaly. This gives us some confidence that the gravity field effectively provides a view of basement topography beneath the evaporites. Version 21 of the gravity field of Sandwell and Smith (2009) shows within the central Red Sea a pattern typical of slow- 
spreading mid-ocean ridge segmentation. The seismic and gravity results together suggest that the central Red Sea is oceanic with a morphology typical of slow-spreading

ridges, contrasting with the southern Red Sea where the higher mantle temperature and faster spreading rate lead to a morphology more typical of ridges over hot mantle such as the Reykjanes Ridge. Between $\sim 23.5^{\circ} \mathrm{N}$ and the continental crust of the northern Red Sea studied by Cochran and Karner (2007), the data are more equivocal, with trends in the gravity field oblique to the plate motions.

The modulation of evaporite flowage by the topography of the underlying basement suggested by Searle and Ross (1975) is locally supported around Thetis Deep by the sense of shear in the evaporites suggested by oblique fabrics imaged with multibeam sonar data. However, the regional pattern of flowage is not so obviously controlled solely by basement topography so other factors may also be important in modulating flowage.

\section{Acknowledgements}

The officers, crew and scientific personnel contributing to the success of the Red Sea 2005 expedition of the RV Urania are thanked, in particular Enrico Bonatti and Marco Ligi. Permissions from the governments of Egypt, Sudan and Saudi Arabia to carry out that work are gratefully acknowledged. The Urania cruise was funded by the Consiglio Nazionale delle Ricerche under project LEC-EMA21F of the European Science Foundation programme EUROMARGINS (contract ERAS-CT-2003-980409 of the European Commission, DG Research FP6). The final multibeam bathymetry was compiled and provided by Marco Ligi. Partial support from NERC grant NE/152880X/1 
is acknowledged. Bill Bosworth kindly shared copies of geological maps of the Red Sea coasts. We are grateful for discussions on aspects of this problem with Marco Ligi, Enrico Bonatti, Jim Cochran, Ian Stewart, Nico Augustin, Peter Feldens, Jerôme Dyment and David Handschumacker. Incisive comments by Bill Bosworth and an anonymous reviewer were very helpful in revising the manuscript. Figures in this article were created with the "GMT" software system (Wessel and Smith, 1991).

\section{References}

Allan, T.P., 1970. Magnetic and Gravity Fields over the Red Sea. Philosophical Transaction of the Royal Society, A267: 153-180.

ArRajehi, A., McClusky, S., Reilinger, R., Daoud, M., Alchalbi, A., Ergintav, S., Gomez, F., Sholan, J., Bou-Rabee, F., Ogubazghi, G., Haileab, B., Fisseha, S., Asfaw, L., Mahmoud, S., Rayan, A., Bendik, R. and Kogan, L., 2010. Geodetic constraints on present-day motion of the Arabian Plate: Implications for Red Sea and Gulf of Aden rifting. Tectonics, 29: Paper TC3011, doi:3010.1029/2009TC002482.

Augustin, N., Devey, C.W., Feldens, P., van der Zwan, F.M., Tominaga, M., Bantan, R., and Kwasnitschka, T., 2014, The transition from rifting to spreading in the Red Sea: Earth Planet. Sci. Lett., v. 395, p. 217-230.

Becker, J.J., Sandwell, D.T., Smith, W.H.F., Braud, J., Binder, B., Depner, J., Fabre, D., Factor, J., Ingalls, S., Kim, S.-H., Ladner, R., Marks, K., Nelson, S., Pharaoh, A., Trimmer, R., Von Rosenberg, J., Wallace, G. and Weatherall, P., 2009. Global Bathymetry and Elevation Data at 30 Arc Seconds Resolution: SRTM30_PLUS. Marine Geodesy, 32: 355-371. 
Begg, G.C., Griffin, W.L., Natapov, I.M., O'Reilly, S.Y., Grand, S.P., O'Neil, C.J., Hronsky, J.M.A., Poudjom-Djomani, Y.H., Swain, C.J., Deen, T. and Bowden, P., 2009. The lithospheric architecture of Africa: Seismic tomography, mantle petrology, and tectonic evolution. Geosphere, 5: 23-50.

Bellahsen, N., Leroy, S., Autin, J., Razin, P., d'Acremont, E., Sloan, H., Pik, R., Ahmed, A. and Khanbari, K., 2013. Pre-existing oblique transfer zones and transfer/transform relationships in continental margins: New insights from the southeastern Gulf of Aden, Socotra Island, Yemen. Tectonophys., 607: 32-50.

Blank, H.R., 1977. Aeromagnetic and geologic study of Tertiary dikes and related structures on the Arabian margin of the Red Sea. in Red Sea Research, 19701975: Saudi Arabian Directorate General of Mineral Resources Bull. 22: G1-G27.

Bleil, U. and Peterson, N., 1983. Variations in magnetisation intensity and lowtemperature titanomagnetite oxidation of ocean floor basalts. Nature, 301: 384388.

Bonatti, E., 1985. Punctiform initiation of seafloor spreading in the Red Sea during transition from a continental to an oceanic rift. Nature, 316: 33-37.

Bonatti, E., Clocchiatti, R., Colantoni, P., Gelmini, R., Marinelli, G., Ottonello, G., Santacroce, R., Taviani, M., Abdel-Meguid, A.A., Asaf, H.S. and El Tahir, M.A., 1983. Zabargad (St. John's) Island: an uplifted fragment of sub-Red Sea lithosphere. J. Geol. Soc. Lond., 140: 677-690.

Bonatti, E., Colantoni, P., Della Vedova, B. and Taviani, M., 1984. Geology of the Red Sea transitional zone $\left(22^{\circ} \mathrm{N}-25^{\circ} \mathrm{N}\right)$. Oceanologica Acta, 7: 385-398.

Bonatti, E. and Seyler, M., 1987. Crustal underplating and evolution in the Red Sea rift: 
Uplifted gabbro/gneiss crustal complexes on Zabargad and Brothers islands. J. Geophs. Res., 92: 12803-12821.

Bosworth, W., Darwish, M., Crevello, P., Taviani, M. and Marshak, S., 1996.

Stratigraphic and structural evolution of Zabargad Island (Red Sea, Egypt) since the Early Cretaceous, Third Int. Conf. Geology of the Arab World, Cairo University, pp. 161-190.

Bosworth, W., Huchon, P. and McClay, K., 2005. The Red Sea and Gulf of Aden basins. J. African Earth Sci., 43: 334-378.

Briais, A. and Rabinowicz, M., 2002. Temporal variations in the segmentation of slow to intermediate spreading mid-ocean ridges. 1. Synoptic observations based on satellite altimetry data. J. Geophys. Res., 107: Paper 2098, doi:2010.1029/2001JB000533.

Camp, V.E., 1984. Island arcs and their role in the evolution of the western Arabian Shield. Geological Society of America Bulletin, 95: 913-921.

Carlson, R.L., 2001. The effects of temperature, pressure, and alteration on seismic properties of diabase dike rocks from DSDP/ODP Hole 504B. Geophys. Res. Lett., 28: 3979-3982.

Carlson, R.L., 2010. How crack porosity and shape control seismic velocities in the upper oceanic crust: Modeling downhole logs from Holes 504B and 1256D. Geochem. Geophys. Geosys., 11: Paper Q04007, doi:04010.01029/02009GC002955.

Carlson, R.L. and Miller, D.J., 1997. A new assessment of the abundance of serpentinite in the oceanic crust. Geophys. Res. Lett., 24: 457-460.

Carlson, R.L. and Miller, D.J., 2004. Influence of pressure and mineralogy on seismic 
velocities in oceanic gabbros: Implications for the composition and state of the lower oceanic crust. J. Geophys. Res., 109: doi:10.1029/2003JB002699.

Chian, D., Louden, K.E., Minshull, T.A. and Whitmarsh, R.B., 1999. Deep structure of the ocean-continent transition in the southern Iberia Abyssal Plain from seismic refraction profiles: Ocean Drilling Program (Legs 149 and 173) transect. J. Geophys. Res., 104: 7443-7462.

Christensen, N.I., 1972. The abundance of serpentinites in the oceanic crust. J. Geol., 80: 709-719.

Christensen, N.I., 1982. Seismic velocities. In: R.S. Carmichael (Editor), Handbook of physical properties of rocks, Vol. II. CRC Press, Inc., pp. 1-228.

Chu, D. and Gordon, R.G., 1998. Current plate motions across the Red Sea. Geophys. J. Int., 135: 313-328.

Cochran, J.R., 1983. A model for the development of the Red Sea. Am. Assoc. Petrol. Geol. Bull., 67: 41-69.

Cochran, J.R., 2005. Northern Red Sea: Nucleation of an oceanic spreading center within a continental rift. Geochemistry, Geophysics, Geosystems, 6: Q03006, doi:03010.01029/02004GC000826.

Cochran, J.R. and Karner, G.D., 2007. Constraints on the deformation and rupturing of continental lithosphere of the Red Sea: the transition from rifting to drifting. In: G.D. Karner, G. Manatschal and L.M. Pinheiro (Editors), Imaging, mapping and modelling continental lithosphere extension and breakup, Geological Society, London Spec. Publ. 282, pp. 265 - 289.

Contrucci, I., Matias, L., Moulin, M., Géli, L., Klingelhöfer, F., Nouzé, H., Aslanian, D., 
Olivet, J.-L., Réhault, J.-P. and Sibuet, J.-C., 2004. Deep structure of the West African continental margin (Congo, Zaïre, Angola), between $5^{\circ} \mathrm{S}$ and $8^{\circ} \mathrm{S}$, from reflection/refraction seismics and gravity data. Geophys. J. Int., 158: 529-553.

Davies, D. and Tramontini, C., 1970. The deep structure of the Red Sea. Philosophical Transaction of the Royal Society, A267: 181-189.

Davison, I., Anderson, L. and Nuttall, P., 2012. Salt deposition, loading and gravity drainage in the Campos and Santos salt basins. In: G.I. Alsop, S.G. Archer, A.J. Hartley, N.T. Grant and R. Hodgkinson (Editors), Salt Tectonics, Sediments and Prospectivity, Geol. Soc. Lond. Spec. Publ. 363, pp. 159-173.

Dean, S.M., Minshull, T.A., Whitmarsh, R.B. and Louden, K.E., 2000. Deep structure of the ocean-continent transition in the southern Iberia Abyssal Plain from seismic refraction profiles' The IAM- 9 transect at $40^{\circ} 20^{\prime} \mathrm{N}$. J. Geophys. Res., 105: 58595885.

Debayle, E., Lévêque, J.-J. and Cara, M., 2001. Seismic evidence for a deeply rooted low-velocity anomaly in the upper mantle beneath the northeastern Afro/Arabian continent. Earth Planet. Sci. Letts., 193: 423-436.

Discovery 215 Working Group, 1998. Deep structure in the vicinity of the oceancontinent transition zone under the southern Iberia Abyssal Plain. Geology, 26: 743-746.

Drake, C.L. and Girdler, R.W., 1964. A Geophysical Study of the Red Sea. Geophys. J. Roy. Astr. Soc., 8: 473-495.

Egloff, F., Rihm, R., Makris, J., Izzeldin, Y.A., Bobsien, M., Meier, K., Junge, P., Noman, T. and Warsi, W., 1991. Contrasting structural styles of the eastern and 
western margins of the southern Red Sea: the 1988 SONNE experiment. Tectonophys., 198: 329-353.

Emery, K.O. and Uchupi, E., 1984. The geology of the Atlantic Ocean. Springer-Verlag, New York.

Evans, R., 1978. Origin and significance of evaporites in basins around Atlantic margin. Bulletin of the American Association of Petroleum Geologists, 62: 223-234.

Faul, U.H. and Jackson, I., 2005. The seismological signature of temperature and grain size variations in the upper mantle. Earth Planet. Sci. Lett., 234: 119-134.

Feldens, P. and Mitchell, N.C., in press. Salt flows in the central Red Sea. In: N. Rasul (Editor), The Red Sea: The formation, morphology, oceanography and environment of a young ocean basin. Springer.

Garfunkel, Z. and Beyth, M., 2006. Constraints on the structural development of Afar imposed by the kinematics of the major surrounding plates. In: G. Yirgu, C.J. Ebinger and P.K.H. Maguire (Editors), The Afar Volcanic Province within the East African Rift System, Geol. Soc. Lond. Spec. Publ. 259, pp. 23-42.

Gaulier, J.-M., LePichon, X., Lyberis, N., Avedik, F. and Moretti, I., 1986. New refraction data on the Northern Red Sea-Gulf of Suez area (abst.). EOS, 67: 1208.

Gaulier, J.M., LePichon, X., Lyberis, N., Avedik, F., Gely, L., Moretti, I., Deschamps, A. and Hafez, S., 1988. Seismic study of the crustal thickness, Northern Red Sea and Gulf of Suez. Tectonophysics, 153: 55-88.

Gilbert, L.A. and Salisbury, M.H., 2011. Oceanic crustal velocities from laboratory and logging measurements of Integrated Ocean Drilling Program Hole 1256D. Geochem. Geophys. Geosys., 12: Paper Q09001, 
doi:09010.01029/02011GC003750.

Girdler, R.W. and Southren, T.C., 1987. Structure and evolution of the northern Red Sea. Nature, 330: 716-721.

Girdler, R.W. and Whitmarsh, R.B., 1974. Miocene evaporites in Red Sea cores, their relevance to the problem of the width and age of oceanic crust beneath the Red Sea. In: R.B. Whitmarsh, O.E. Weser, D.A. Ross, et al. (Editors), Initial Reports of the Deep Sea Drilling Project, Vol. 23. U.S. Govt. Printing Office, Washington, D.C., pp. 913-921.

Haase, K.M., Mühe, R. and Stoffers, P., 2000. Magmatism during extension of the lithosphere: geochemical constraints from lavas of the Shaban Deep, northern Red Sea. Chemical Geology, 166: 225-239.

Hammer, P.T.C., Hildebrand, J.A. and Parker, R.L., 1991. Gravity inversion using seminorm minimization: Density modeling of Jasper Seamount. Geophysics, 56: 68-79.

Hildebrand, J.A., Stevenson, J.M., Hammer, P.T.C., Zumberge, M.A., Parker, R.L., Fox, C.G. and Meis, P.J., 1990. A seafloor and sea surface gravity survey of Axial Volcano. J. Geophys. Res., 95: 12751-12763.

Izzeldin, A.Y., 1987. Seismic, gravity and magnetic surveys in the central part of the Red Sea: their interpretation and implications for the structure and evolution of the Red Sea. Tectonophysics, 143: 269-306.

Izzeldin, A.Y., 1989. Transverse structures in the central part of the Red Sea and implications on early stages of Oceanic Accretion. Geophys. J., 96: 117-129. Jackson, M.P.A., Cramez, C. and Fonck, J.-M., 2000. Role of subaerial volcanic rocks 
and mantle plumes in creation of South Atlantic margins: implications for salt tectonics and source rocks. Marine and Petroleum Geology, 17: 477-498.

Jull, M. and McKenzie, D., 1996. The effect of deglaciation on mantle melting beneath Iceland. J. Geophys. Res, 101: 21815-21828.

Karner, G.D. and Gamboa, L.A.P., 2007. Timing and origin of the South Atlantic pre-salt sag basins and their capping evaporites. In: B.C. Schreiber, S. Lugli and M. Babel (Editors), Evaporites through space and time. Geol. Soc. Lond. Spec. Publ. 285, pp. 15-35.

Klein, E.M. and Langmuir, C.H., 1987. Global correlations of ocean ridge basalt chemistry with axial depth and crustal thickness. J. Geophys. Res., 92: 8089-8115.

Klitzsch, E., List, F.K., Pöhlmann, G., Handley, R., Hermina, M. and Meissner, B., 1987. Geological Map of Egypt 1:500,000. Egyptian General Petroleum Corporation, Cairo, Egypt.

LaBrecque, J.L. and Zitellini, N., 1985. Continuous seafloor spreading in the Red Sea: An alternative interpretation of the magnetic anomaly pattern. A.A.P.G. Bull., 69: 513-524.

Levi, S. and Riddihough, R., 1986. Why are marine magnetic anomalies suppressed over sedimented spreading centres? Geology, 14: 651-654.

Ligi, M., Bonatti, E., Bortoluzzi, G., Cipriani, A., Cocchi, L., Caratori Tontini, F., Carminati, E., Ottolini, L. and Schettino, A., 2012. Birth of an ocean in the Red Sea: Initial pangs. Geochem. Geophys. Geosys., 13: Paper Q08009, doi:08010.01029/02012GC004155.

Ligi, M., Bonatti, E., Tontini, F.C., Cipriani, A., Cocchi, L., Schettino, A., Bortoluzzi, G., 
Ferrante, V., Khalil, S., Mitchell, N.C. and Rasul, N., 2011. Initial burst of oceanic crust accretion in the Red Sea due to edge-driven mantle convection. Geology, 39: 1019-1022.

Lin, J., Purdy, G.M., Schouten, H., Sempere, J.-C. and Zervas, C., 1990. Evidence from gravity data for focused magmatic accretion along the Mid-Atlantic Ridge. Nature, 344: 627-632.

Maclennan, J., Jull, M., McKenzie, D., Slater, L. and Gronvöld, K., 2002. The link between volcanism and deglaciation in Iceland. Geochem. Geophys. Geosys., 3: Paper 1062, doi:1010.1029/2001GC000282.

Makris, J., Tsironidis, J. and Richter, H., 1991. Heatflow density distribution in the Red Sea. Tectonophys., 198: 383-393.

Manheim, F.T., Dwight, L. and Belastock, R.A., 1974. Porosity, density, grain density, and related physical properties of sediments from the Red Sea drill cores. In: R.B. Whitmarsh, O.E. Weser, D.A. Ross, et al. (Editors), Initial Reports of the Deep Sea Drilling Project, Vol. 23. U.S. Govt. Printing Office, Washington, D.C., pp. 887-907.

Marks, K.M., Smith, W.H.F. and Sandwell, D.T., 2013. Significant improvements in marine gravity from ongoing satellite missions. Mar. Geophys. Res., 34: 137-146.

Marshak, S., Bonatti, E., Brueckner, H. and Paulsen, T., 1992. Fracture-zone tectonics at Zabargad Island, Red Sea (Egypt). Tectonophys., 216: 379-385.

Martinez, F. and Cochran, J.R., 1988. Structure and tectonics in the northern Red Sea: catching a continental margin between rifting and drifting. Tectonophys., 150: 132. 
McClusky, S., Reilinger, R., Mahmoud, S., Ben Sari, D. and Tealeb, A., 2003. GPS constraints on Africa (Nubia) and Arabia plate motions. Geophys. J. Int., 155: 126-138.

Mechie, J. and Prodehl, C., 1988. Crustal and uppermost mantle structure beneath the Afro-Arabian rift system. Tectonophys., 153: 103-121.

Milkereit, B. and Fluh, E.R., 1985. Saudi Arabian refraction profile: Crustal structure of the Red Sea-Arabian Shield transition. Tectonophysics, 111: 283-298.

Mitchell, N.C., Ligi, M., Farrante, V., Bonatti, E. and Rutter, E., 2010a. Submarine salt flows in the central Red Sea. Geological Society of America Bulletin, 122: 701713.

Mitchell, N.C., Schmidt, M. and Ligi, M., 2010b. Comment on "Formation of Thetis Deep metal-rich sediments in the absence of brines, Red Sea" by Pierret et al. (2010). J. Geochem. Expl., 108: 112-113.

Mitchell, N. C., in press, Lineaments in gravity data of the Red Sea, in Rasul, N., ed., The Red Sea: The formation, morphology, oceanography and environment of a young ocean basin, Springer.

Moulin, M., Aslanian, D., Olivet, J.-L., Contrucci, I., Matias, L., Géli, L., Klingelhoefer, F., Nouzé, H., Réhault, J.-P. and Unternehr, P., 2005. Geological constraints on the evolution of the Angolan margin based on reflection and refraction seismic data (ZaïAngo project). Geophys. J. Int., 162: 793-810.

Mutter, C.Z. and Mutter, J.C., 1993. Variations in thickness of layer 3 dominate oceanic crustal structure. Earth Planat. Sci. Lett., 117: 295-317.

Mutter, J., Talwani, M. and Stoffa, P.L., 1982. Origin of seaward-dipping reflectors in 
oceanic crust off the Norwegian Margin by "subaerial seafloor spreading". Geology, 10: 353-357.

Orszag-Sperber, F., Harwood, G., Kendall, A. and Purser, B.H., 1998. Review of the evaporites of the Red Sea-Gulf of Suez rift. In: B.H. Purser and D.W.J. Bosence (Editors), Sedimentation and tectonics of rift basins: Red Sea-Gulf of Aden. Chapman \& Hall, London, pp. 409-426.

Park, Y., Nyblade, A.A., Rodgers, A.J. and Al-Amri, A., 2007. Upper mantle structure beneath the Arabian Peninsula and northern Red Sea from teleseismic body wave tomography: Implications for the origin of Cenozoic uplift and volcanism in the Arabian Shield. Geochem. Geophys. Geosys., 8: Paper Q06021, doi:06010.01029/02006GC001566.

Park, Y., Nyblade, A.A., Rodgers, A.J. and Al-Amri, A., 2008. S wave velocity structure of the Arabian Shield upper mantle from Rayleigh wave tomography. Geochem. Geophys. Geosys., 9: Paper Q07020, doi:07010.01029/02007GC001895.

Pasyanos, M.E. and Nyblade, A.A., 2007. A top to bottom lithospheric study of Africa and Arabia. Tectonophys., 444: 27-44.

Pautot, G., 1983. Red Sea deeps-A geomorphological study by Seabeam. Oceanol. Acta, 6: 235-244.

Pautot, G., Guennoc, P., Coutelle, A. and Lyberis, N., 1984. Discovery of a large brine deep in the northern Red Sea. Nature, 310: 133-136.

Peach, C.J., 1991. Influence of deformation on the fluid transport properties of salt rocks. $\mathrm{PhD}$ Thesis, University of Utrecht, Utrecht, Netherlands, $238 \mathrm{pp}$.

Priestly, K., McKenzie, D., Debayle, E. and Pilidou, S., 2008. The African upper mantle 
and its relationship to tectonics and surface geology. Geophys J. Int., 175: 11081126.

Prodehl, C., 1985. Interpretation of a seismic-refraction survey across the Arabian Shield in western Saudi Arabia. Tectonophysics, 111: 247-282.

Purdy, G.M., Kong, L.S.L., Christeson, G.L. and Solomon, S.C., 1992. Relationship between spreading rate and the seismic structure of mid-ocean ridges. Nature, 355: 815-817.

Ritsema, J. and van Heijst, H., 2000. New seismic model of the upper mantle beneath Africa. Geology, 28: 63-66.

Roeser, H.A., 1975. A detailed magnetic survey of the southern Red Sea. Geol. Jahrb. 13: 131-153.

Rona, P.A., 1982. Evaporites at passive margins. In: R.A. Scrutton (Editor), Dynamics of passive margins. Am. Geophys. Union and Geol. Soc. Am., pp. 116-132.

Ross, D.A. and Schlee, J., 1973. Shallow structure and geologic development of the southern Red Sea. Geol. Soc. Am. Bull., 84: 3827-3848.

Rudnick, R.L. and Fountain, D.M., 1995. Nature and composition of the continental crust: a lower crustal perspective. Rev. Geophys., 33: 267-309.

Sandwell, D.T. and Smith, W.H.F., 1997. Marine gravity anomaly from Geosat and ERS1 satellite altimetry. J. Geophys. Res., 102: 10039-10054.

Sandwell, D.T. and Smith, W.H.F., 2009. Global marine gravity from retracked Geosat and ERS-1 altimetry: Ridge segmentation versus spreading rate. J. Geophys. Res., 114: Paper B01411, doi:01410.01029/02008JB006008.

Schouten, H., Dick, H.J.B. and Klitgord, K.D., 1987. Migration of mid-ocean ridge 
volcanic segments. Nature, 326: 835-839.

Searle, R.C. and Ross, D.A., 1975. A geophysical study of the Red Sea axial trough between $20.5^{\circ}$ and $22^{\circ}$ N. Geophys. J. Roy. Astr. Soc., 43: 555-572.

Sempere, J.C., Purdy, G.M. and Schouten, H., 1990. Segmentation of the Mid-Atlantic Ridge between $24^{\circ} \mathrm{N}$ and $30^{\circ} 40^{\prime} \mathrm{N}$. Nature, $344: 427-431$.

Sicilia, D., Montagner, J.-P., Cara, M., Stutzmann, E., Debayle, E., Lépine, J.-C., Lévêque, J.-J., Beucler, E., Sebai, A., Roult, G., Ayele, A. and Sholan, J.M., 2008. Upper mantle structure of shear-waves velocities and stratification of anisotropy in the Afar Hotspot region. Tectonophys., 462: 164-177.

Sinha, M.C., Navin, D.A., MacGregor, L.M., Constable, S., Pierce, C., White, A., Heinson, G. and Inglis, M.A., 1997. Evidence for accumulated melt beneath the slow-spreading Mid-Atlantic Ridge. Philosophical Transactions of the Royal Society of London. Series A, 355: 233-253.

Slater, L., Jull, M., McKenzie, D. and Gronvöld, K., 1998. Deglaciation effects on mantle melting under Iceland: results from the northern volcanic zone. Earth Panet. Sci. Lett., 164: 151-164.

Smith, W.H.F. and Sandwell, D.T., 1997. Global sea floor topography from satellite altimetry and ship soundings. Science, 277: 1956-1962.

Spiers, C.J., Schutjens, P.M.T.M., Brzesowsky, R.H., Peach, C.J., Liezenberg, J.L. and Zwart, H.J., 1990. Experimental determination of constitutive parameters governing creep of rocksalt by pressure solution. In: R.J. Knipe and E.H. Rutter (Editors), Deformation mechanisms, rheology and tectonics, Geol. Soc. Lond. Spec. Publ. 54, pp. 215-227. 
Stern, R.J. and Johnson, P., 2010. Continental lithosphere of the Arabian Plate: A geologic, petrologic, and geophysical synthesis. Earth-Science Reviews, 101: 2967.

Stoeser, D.B. and Camp, V.E., 1985. Pan-African microplate accretion of the Arabian Shield. Geological Society of America Bulletin, 96: 817-826.

Swift, S., Reichow, M., Tikka, A., Tominaga, M. and Gilbert, L., 2008. Velocity structure of upper ocean crust at Ocean Drilling Program Site 1256. Geochem. Geophys. Geosys., 9: Paper Q10O13, doi:10.1029/2008GC002188.

Telford, W.M., Geldart, L.P., Sheriff, R.E. and Keys, D.A., 1976. Applied Geophysics. Cambridge University Press, New York, 860 pp.

Tramontini, C. and Davies, D., 1969. A seismic refraction survey in the Red Sea. Geophys. J. R. Astr. Soc., 17: 225-241.

Urai, J.L., Spiers, C.J., Zwart, H.J. and Lister, G.S., 1986. Weakening of rock salt by water during long-term creep. Nature, 324: 554-557.

van der Zwan, F.M., Augustin, N., Devey, C.W., Bantan, R. and Kwasnitschka, T., 2013. New insights into volcanism and tectonics in the Red Sea Rift. Geophysical Research Abstracts, European Geoscience Union, 15: EGU2013-7188.

Vine, F.J., 1966. Spreading of the ocean floor - new evidence. Science, 154: 1405-1415. Vine, F.J. and Matthews, D.H., 1963. Magnetic anomalies over oceanic ridges. Nature, 199: 947-949.

Wepfer, W.W. and Christensen, N.I., 1991. A seismic velocity-confining pressure relation with applications. Int. J. Rock Mech. Min. Sci Geomech. Abstr., 28: 451456. 
Wessel, P. and Smith, W.H.F., 1991. Free software helps map and display data. Eos, Transactions, American Geophysical Union, 72: 441.

Wheildon, J., Evans, T.R. and Girdler, R.W., 1974. Thermal conductivity, density, and sonic velocity measurements of samples of anhydrite and halite from Sites 225 and 227. In: R.B. Whitmarsh, O.E. Weser, D.A. Ross, et al. (Editors), Initial Reports of the Deep Sea Drilling Project, Vol. 23. U.S. Govt. Printing Office, Washington, D.C., pp. 909-911.

Whitmarsh, R.B. and Wallace, P.J., 2001. The rift-to-drift development of the west Iberia nonvolcanic continental margin: a summary and review of the contribution of Ocean Drilling Program Leg 173. In: M.-O. Beslier, R.B. Whitmarsh, P.J. Wallace and J. Girardeau (Editors), Proc. ODP, Sci. Results, 173. Ocean Drill. Progr., College Station, TX, pp. 1-36.

Whitmarsh, R.B., Weser, O.E. and Ross, D.A., 1974. Initial Reports of the Deep Sea Drilling Project, 23B. U. S. Government Printing Office, Washington, D. C.

Whitmarsh, R.B., White, R.S., Horsefield, S.J., Sibuet, J.-C., Recq, M. and Louvel, V., 1996. The ocean-continent boundary off the western continental margin of Iberia: Crustal structure west of Galicia Bank. J. Geophs. Res., 101: 28291-28314.

Zahran, H.M., Stewart, I.C.F., Johnson, P.R. and Basahel, M.H., 2003. Aeromagneticanomaly maps of central and western Saudi Arabia. Saudi Geological Survey. Scale 1:2 million. Saudi Geological Survey Open-File Report SGS-OF-2002-8.

\section{Figures}




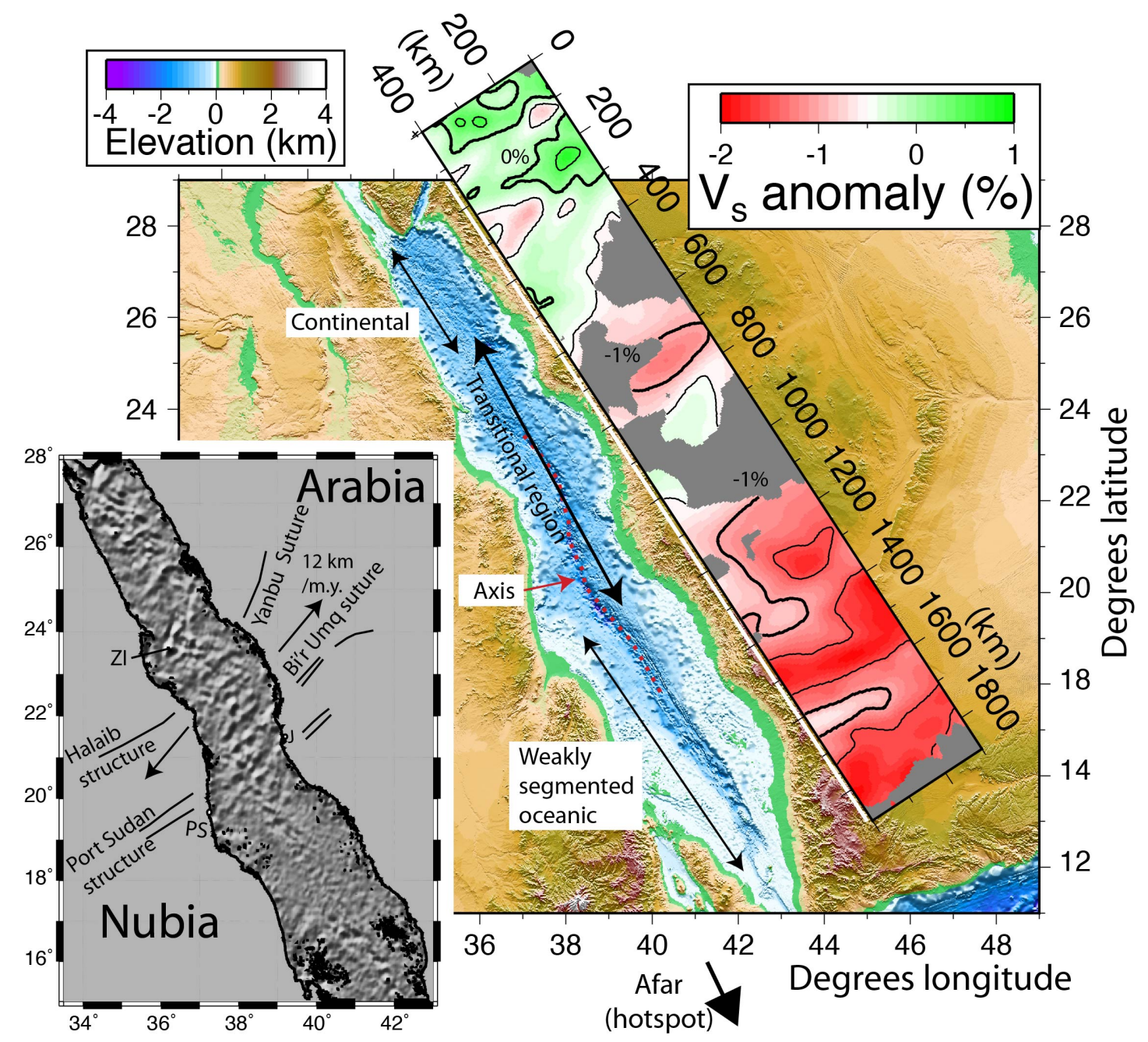

Figure 1. Overview of the Red Sea physiography and upper mantle velocity structure.

Elevations are from Becker et al. (2009) and are shown with a simple linear map

projection to preserve latitudinal distances (spacing of latitude degrees is uniform up the

page). Vertical cross-section of the upper mantle $V_{s}$ structure shown is from Park et al. (2007, their B-B' slice) based on teleseismic delays recorded at stations mainly on the Arabian peninsular. The line of the section (white line) runs along the base of the $\mathrm{V}_{\mathrm{s}}$ anomaly graph (distances shown are in $\mathrm{km} ; \mathrm{V}_{\mathrm{s}}$ data are plotted at the same scale as the map). $\mathrm{V}_{\mathrm{s}}$ contours are shown every $0.5 \%$ with $1 \%$ changes in bold. Areas of poor ray coverage are shown grey. Inset (lower-left) shows the configuration of the continental 
areas and major crustal lineaments of the African-Arabian shield (see text for details).

Grey image in sea areas is from version 18 of the satellite-derived marine gravity field (Sandwell and Smith, 1997) shaded from N030 ${ }^{\circ}$ W. Plate separation rate shown is the full spreading rate at $21.5^{\circ} \mathrm{N}$ computed from the pole of Chu and Gordon (1998). Further annotation: (ZI) Zabargad Island, (J) Jeddah and (PS) Port Sudan.

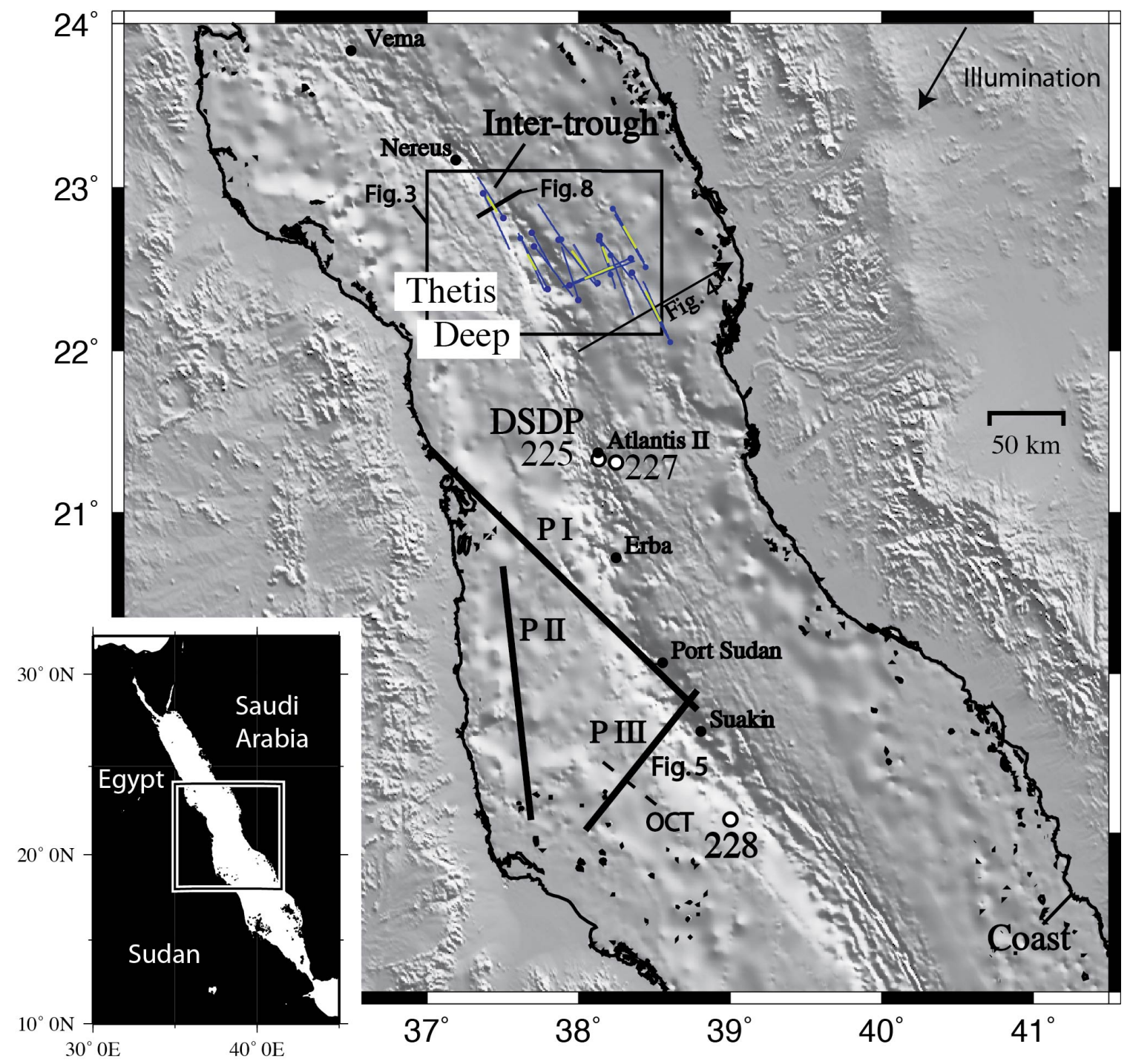

Figure 2. Locations of datasets in the central Red Sea with a shaded relief view of the topographic / bathymetry grid of Becker et al. (2009) as background (note NW-SE 
lineaments in centre are ship-track artefacts). Small solid circles and bold text ("Vema", etc) are a selection of the deeps from Pautot et al. (1984). Three large black-outlined open circles locate DSDP Sites 225 and 227 adjacent to Atlantis-II Deep and Site 228 farther south. Blue lines in and around Thetis Deep locate the seismic refraction experiments (Tramontini and Davies, 1969) summarized in Figure 4, with solid blue circles marking the sonobuoy locations (pairs of lines highlighted in yellow were used for their dipping-layer calculations). Three bold lines near Suakin Deep locate refraction profiles P I to III of Egloff et al. (1991). Dashed line marked "OCT" locates the oceancontinent transition in their P III velocity model. Solid line in the Thetis-Nereus intertrough zone locates the seismic data interpretation in Figure 8.

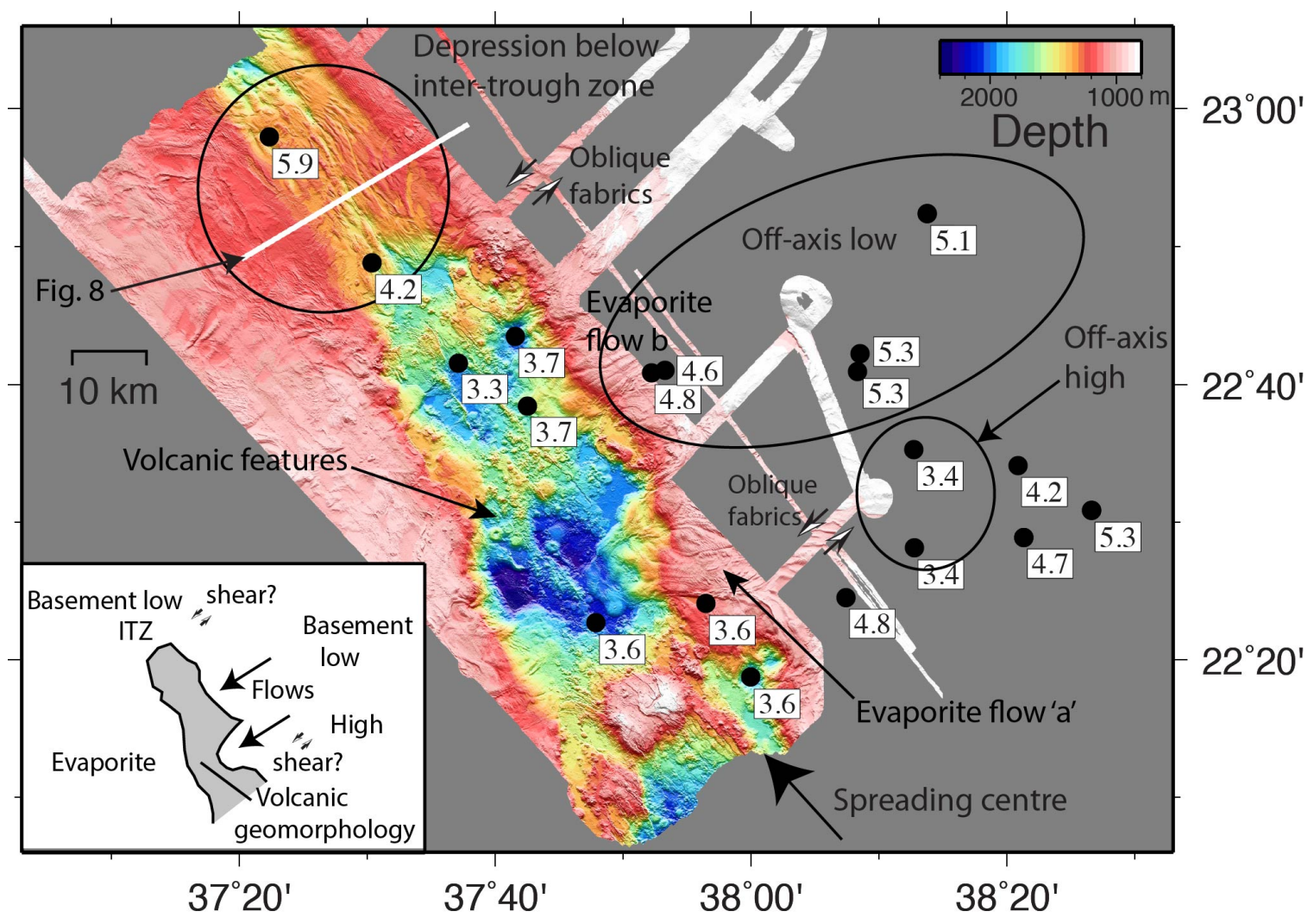


Figure 3. Shaded relief image of multibeam sonar bathymetry of Thetis Deep. Values on white boxes are depths below sea level $(\mathrm{km})$ to the crustal seismic refractor of Tramontini and Davies (1969). Artificial illumination is from due north. Areas lacking data are left mid-grey. Annotations "a" and "b" mark two features interpreted as evaporite flows (Mitchell et al., 2010a). Two sets of double arrows with annotation "Oblique fabrics" mark regions of apparent shear in the evaporites. Ellipses highlight regions discussed in the text. Inset lower-left shows a generalized interpretation of the main panel (grey areas contain volcanic morphologies, white areas evaporite morphologies).

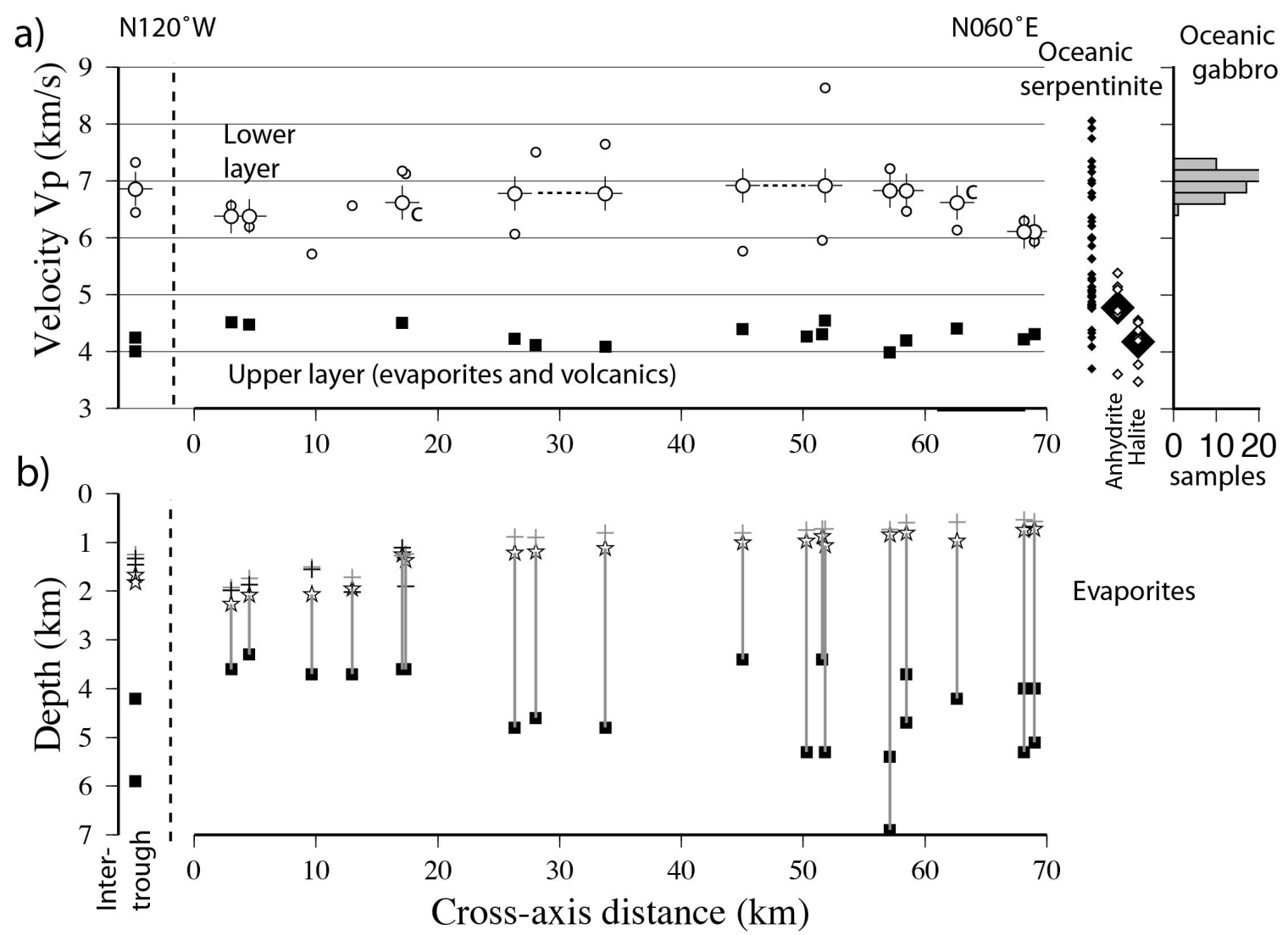

Figure 4. Results of seismic refraction experiments (Davies and Tramontini, 1970;

Tramontini and Davies, 1969) carried out along the lines shown in Figure 2. The data are 
shown at the sonobuoy locations, which have been projected $\mathrm{N} 150^{\circ} \mathrm{E}$ onto the line oriented $\mathrm{N} 060^{\circ} \mathrm{E}$ from $22^{\circ} \mathrm{N}, 38^{\circ} \mathrm{E}$ marked by the solid arrow in Figure 2 (i.e., "cross-axis distance" is parallel to this line), apart from the inter-trough values shown on the left. (a) Velocity of upper layer (solid squares) and lower layer (open circles) for the lines shown in Figure 2. Small circles are single refraction line velocities. Larger circles underlain with plus symbols were calculated by Tramontini and Davies (1969) by pairing up the profiles and deriving a single velocity for a dipping layer (dashed lines connect the two sonobuoy positions). Two values marked 'c' were shot across-axis. On the right, solid diamond symbols represent $V_{p}$ measurements on variably serpentinized peridotite at 200 MPa (Carlson and Miller, 1997; Christensen, 1972; Christensen, 1982). Open diamonds show $\mathrm{V}_{\mathrm{p}}$ measurements on anhydrite and halite samples recovered at the DSDP sites (Figure 2) by Wheildon et al. (1974) and large solid diamond symbols are their averages. Histogram to the right shows the distribution of $\mathrm{V}_{\mathrm{p}}$ values measured at $200 \mathrm{MPa}$ on unaltered samples of oceanic gabbro (Carlson and Miller, 2004). (b) The depths of an interpreted seismic refractor are represented by solid squares at the sonobuoy locations. Seafloor depths at the buoys are from (solid crosses) the multibeam bathymetry or (grey crosses) bathymetry derived from satellite altimetry data and echo-soundings (Smith and Sandwell, 1997). Star symbols represent the mean bathymetry of each site derived from seabed reflections in the seismic experiment. 


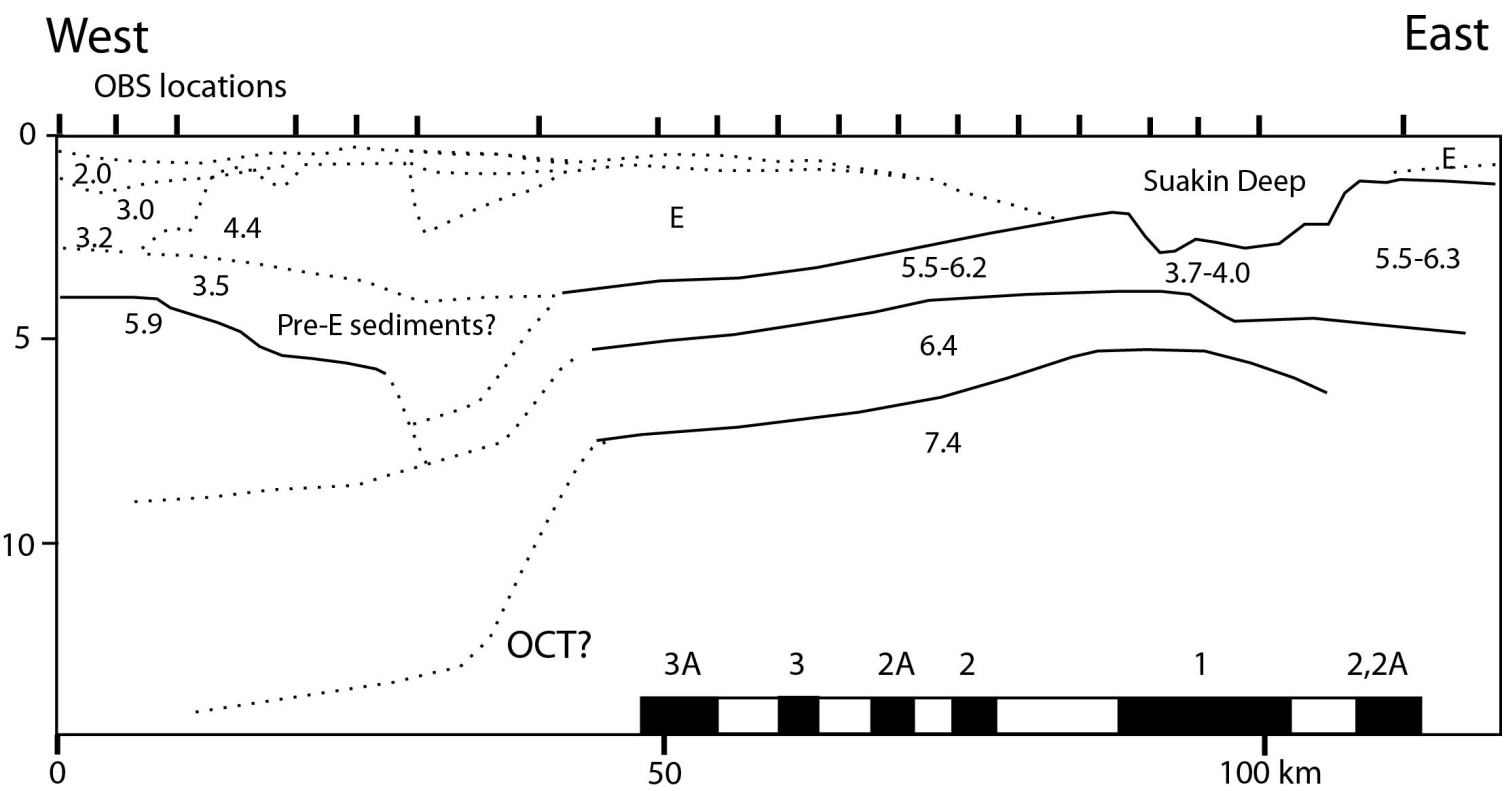

Figure 5. Seismic velocity $\left(\mathrm{V}_{\mathrm{p}}\right)$ model of Egloff et al. (1991) for the line located in Figure 2 (RV Sonne cruise 53 line P III). Solid lines are boundaries delimited by refracted arrivals whereas dotted lines are delimited by reflections only. Small numbers on the model are velocities in $\mathrm{km} \mathrm{s}^{-1}$. Solid bars at base of diagram are normal polarity sea-floor magnetic anomalies originally identified by Izzeldin (1987). E: evaporites, OCT: ocean-continent boundary. 


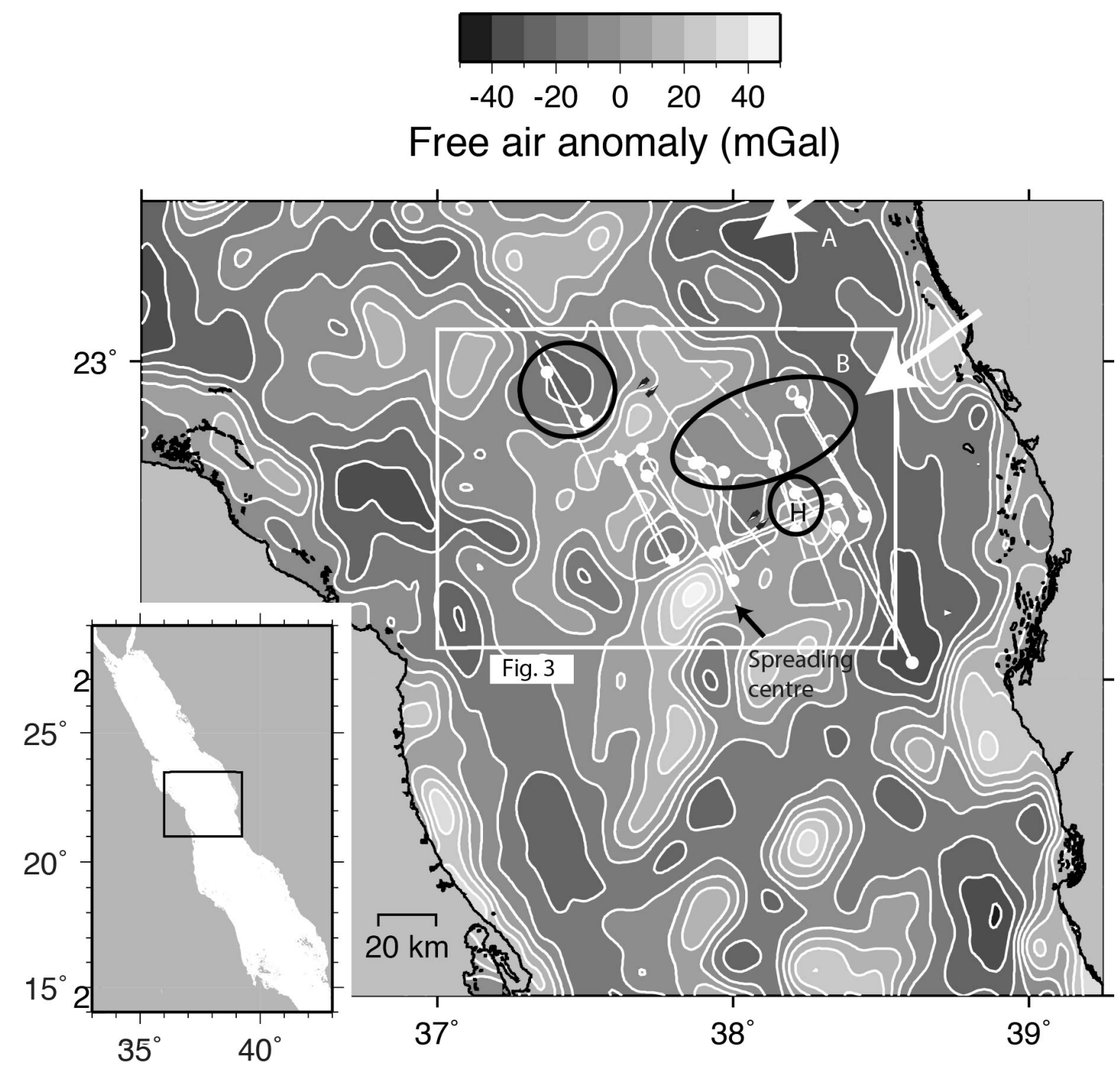

Figure 6. Version 21 of the free-air anomaly field derived from satellite altimetry measurements by Sandwell and Smith (1997) for the Thetis Deep area (located in lowerleft inset). The data are contoured at $10 \mathrm{mGal}$ intervals. White lines and outline of Figure 3 as in Figure 2. White arrows marked "A" and "B" highlight two ridgeperpendicular trends of gravity lows (note that the trends terminate at the position of the arrow heads without continuing to the coastline). Annotation "H" locates a gravity high corresponding with the elevated refractor in Figure 3 (a seamount?). Other annotations (ellipses and double arrows) are the same as those in Figure 3. 

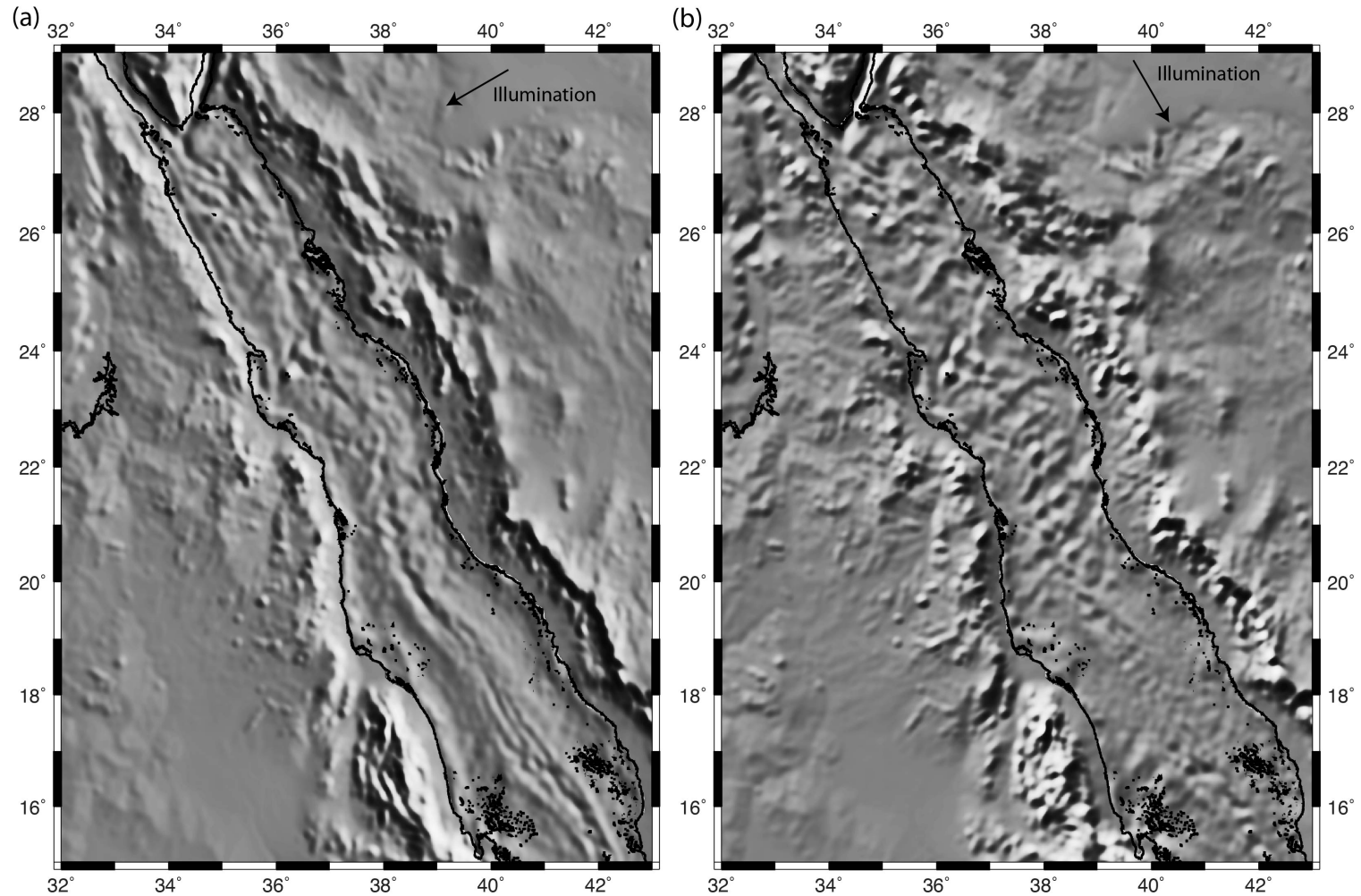


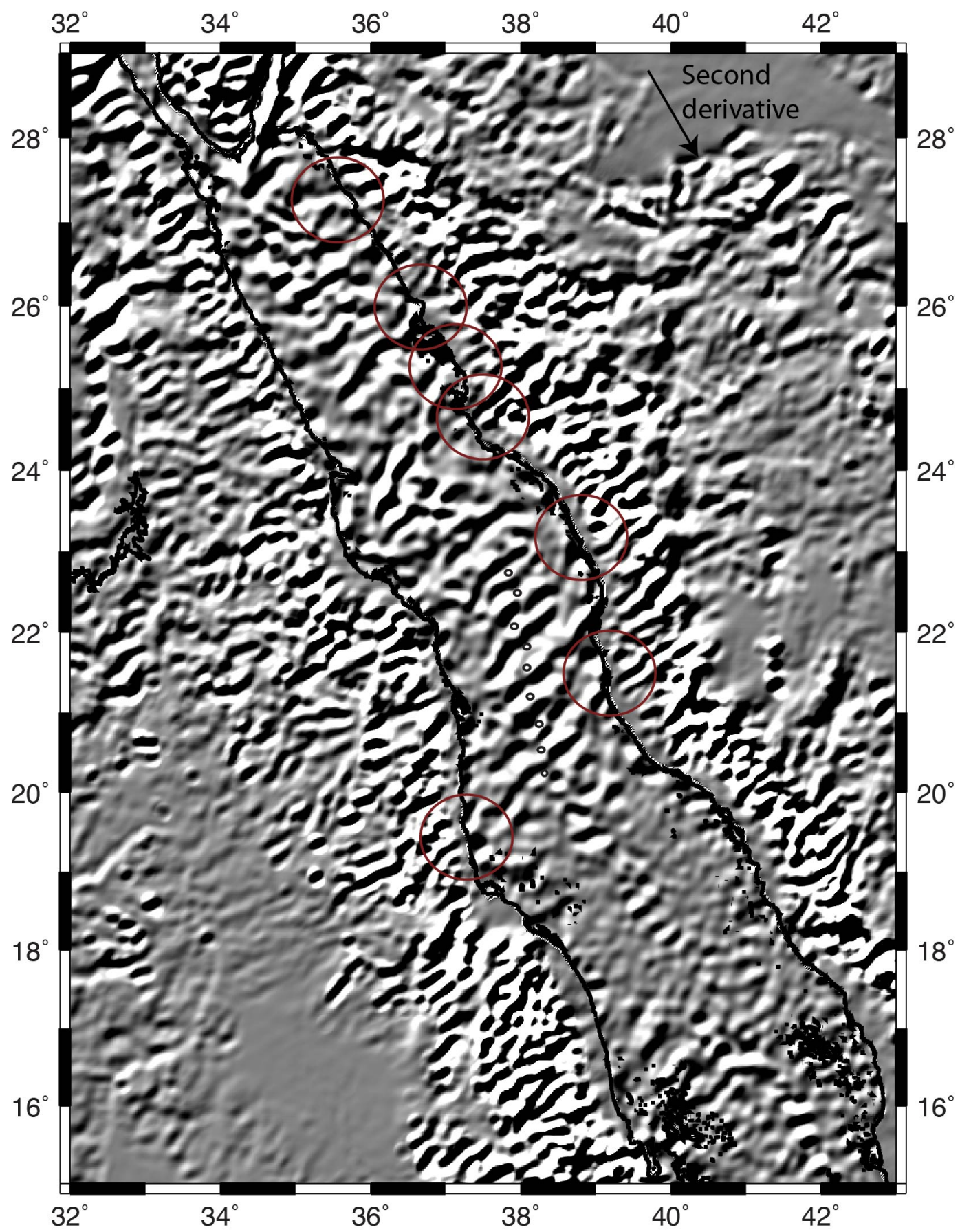

Figure 7. Maps of version 21 of the marine gravity field (Sandwell and Smith, 1997) and elevation data (Becker et al., 2009) onshore. To enhance structure, some simple image processing operations have been applied to the two datasets. In (a) and (b), the data are shaded as though a common topographic surface with the illumination directions $\mathrm{N} 060^{\circ} \mathrm{E}$ 
and $\mathrm{N} 30^{\circ} \mathrm{W}$, respectively, shown at top-right in each panel. In (c), the data second derive was computed with the direction shown so that black represents downward curved areas (e.g., ridge crests and convex-upward breaks of slope) and white represents upwardcurved areas (valleys or concave-upward breaks in slope). Dark red circles highlight a selection of lineaments apparently aligned in the two data types. Small unfilled ellipses mark where across-axis gravity lows are interpreted to intersect the spreading axis.

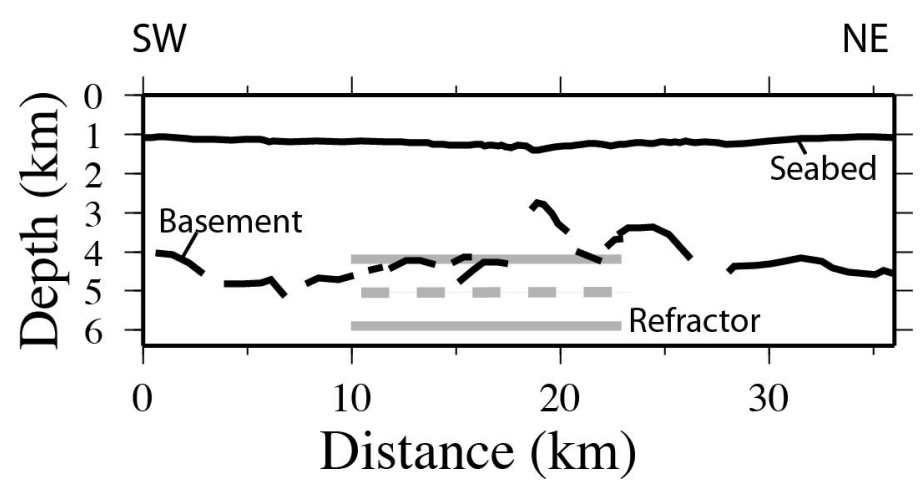

Figure 8. Structure of the Nereus-Thetis inter-trough zone from (solid lines) interpretation of seismic reflection profile 5 of Izzeldin (1989) and (bold grey lines) depths of two refractors obtained by Tramontini and Davies (1969); grey dashed line is average depth of the two refractors. Survey lines are located in Figure 2. The basement reflector has been depth converted using a mean evaporite velocity of $4.26 \mathrm{~km} \mathrm{~s}^{-1}$ from Tramontini and Davies (1969) and water velocity of $1.5 \mathrm{~km} \mathrm{~s}^{-1}$. 
a)

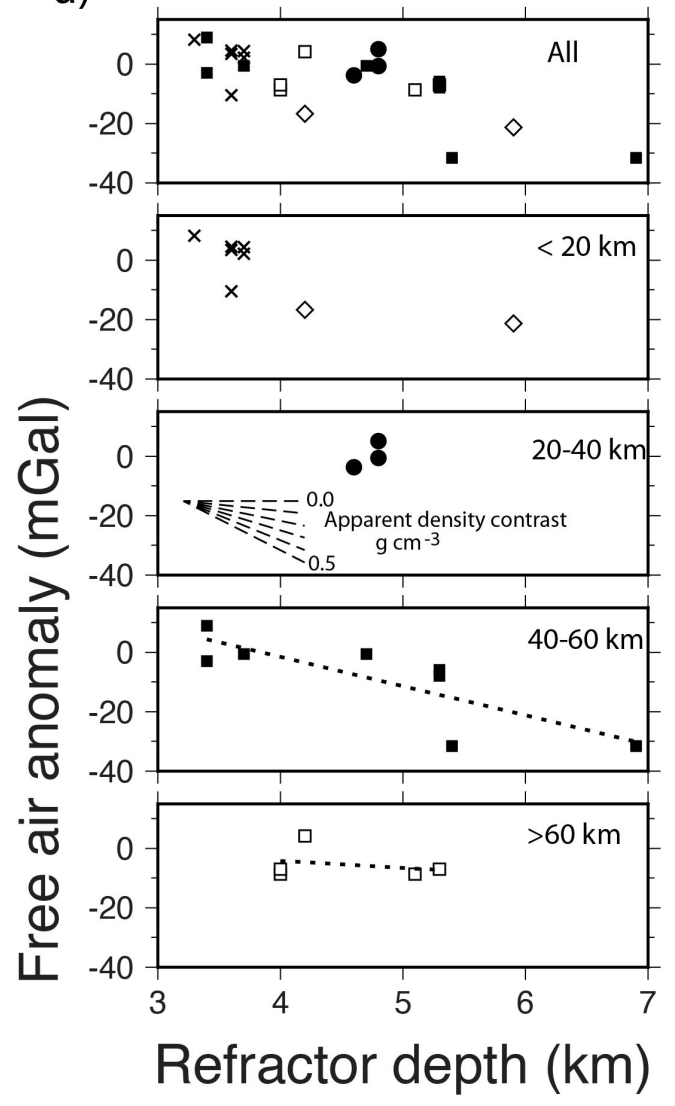

b)

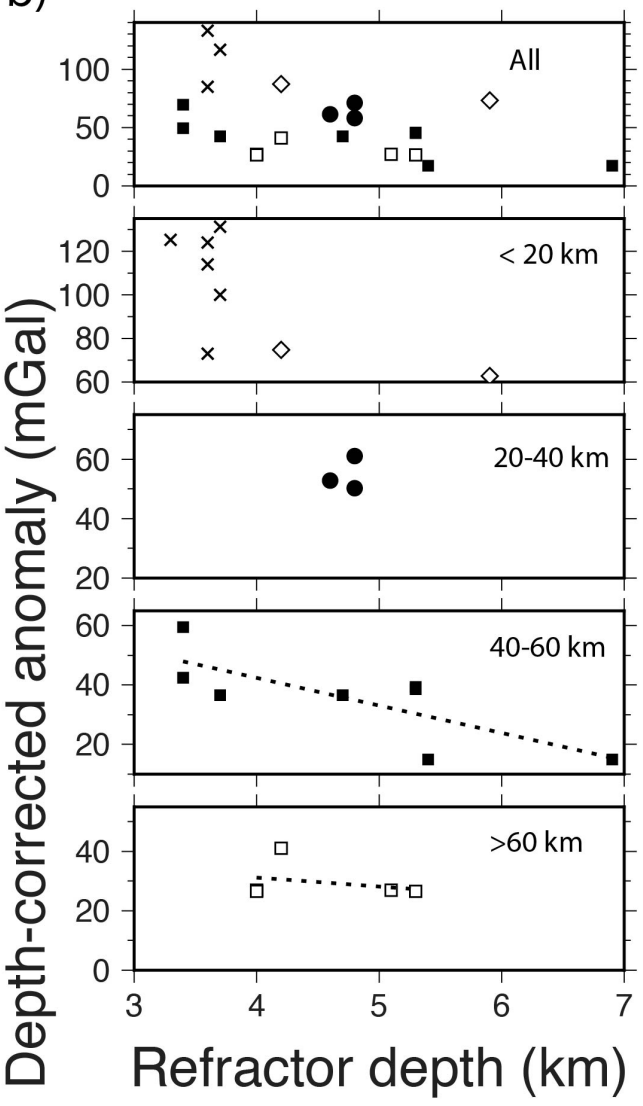

Figure 9. Variation in gravity anomaly with depth to the refractor of Tramontini and Davies (1969) at different distances from the spreading axis (distances given in upperright of each graph) where the gravitational effect of the upper mantle progressively cooling away from the axis (Lin et al., 1990) should be roughly common to each group. Symbols in top graph (showing all data) correspond with those in lower graphs. Within the near-axis dataset $(<20 \mathrm{~km})$, diamond symbols represent values from the inter-trough zone. Dotted lines are least-squares regressions for the graphs shown. For comparison, oblique dashed lines on the $20-40 \mathrm{~km}$ graph are trends expected with various apparent density contrasts predicted using the slab formula (2). (a) Correlation with gravity freeair anomaly (v21 of Sandwell and Smith, 2009). (b) Correlations with anomalies corrected using the slab formula for a $1.5 \mathrm{~g} \mathrm{~cm}^{-3}$ density contrast between evaporites and 
water (i.e., Bouguer corrected). (For comparison, Cochran and Karner (2007) used a density contrast of $1.37 \mathrm{~g} \mathrm{~cm}^{-3}$ for their Bouguer anomaly calculation and Izzeldin (1987) assuming a pure halite evaporite body used $1.18 \mathrm{~g} \mathrm{~cm}^{-3}$.) Note scales in top two graphs in (b) are different from the others.

a)

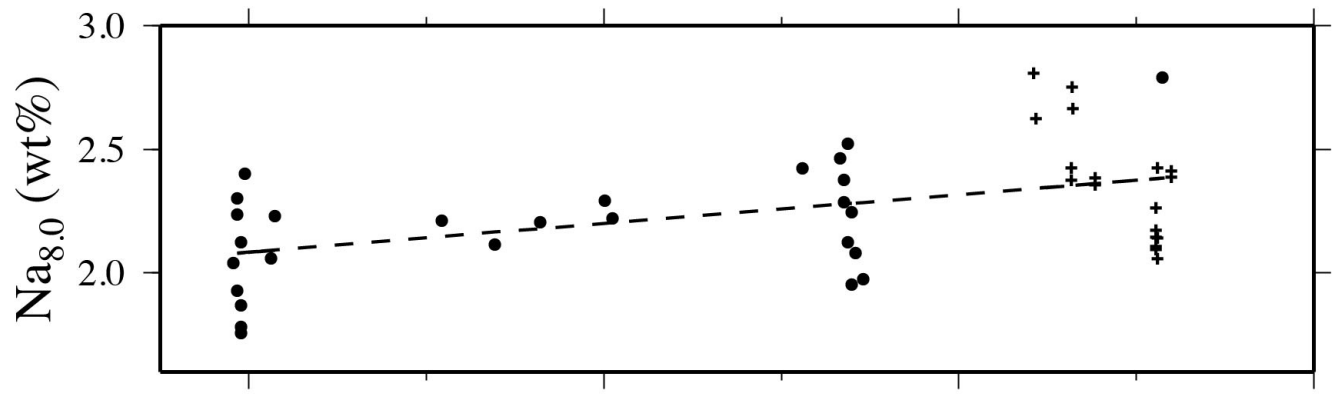

b)

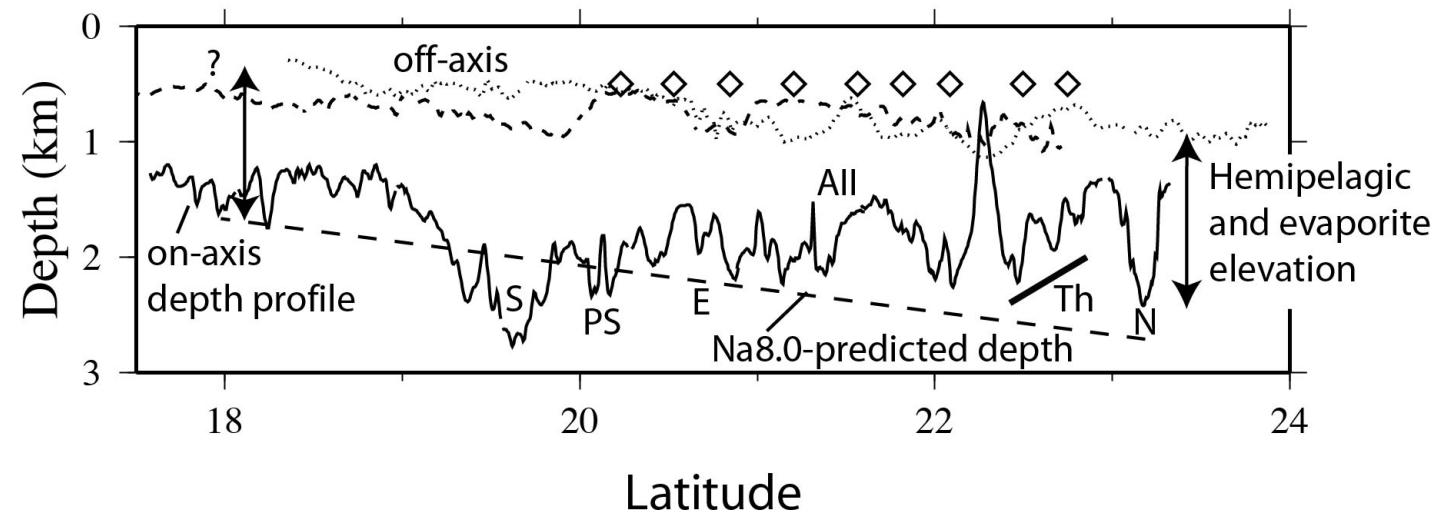

Figure 10. (a) Sodium oxide contents of axial lavas corrected for shallow level fractionation (to $8 \% \mathrm{MgO}$ ) from (solid circles) compilation of Haase et al. (2000) and (plus symbols) from Ligi et al. (2012). Dashed line is a least-squares regression through the data. (b) Depths along the spreading axis (continuous line) and off-axis lines shown in Figure 12 (dotted and dashed irregular lines) sampled from the bathymetry of Becker et al. (2009). Straight dashed line is axial depth variation predicted using the trend in the global $\mathrm{Na}_{8.0}$ dataset of Klein and Langmuir (1987) and the regression line in (a). Vertical lines with double arrows highlight the elevation of the evaporites over the floors of the 
deeps, which increases modestly northwards on average. Annotation represents a selection of the deeps of Pautot et al. (1984): (S) Suakin, (PS) Port Sudan, (E) Erba, (AII) Atlantis II, (Th) Thetis and (N) Nereus Deep. Open diamond symbols are along-axis gravity lows interpreted from the 2nd derivative in Figure 7c (corresponding with the positions of the ellipses in that figure). 


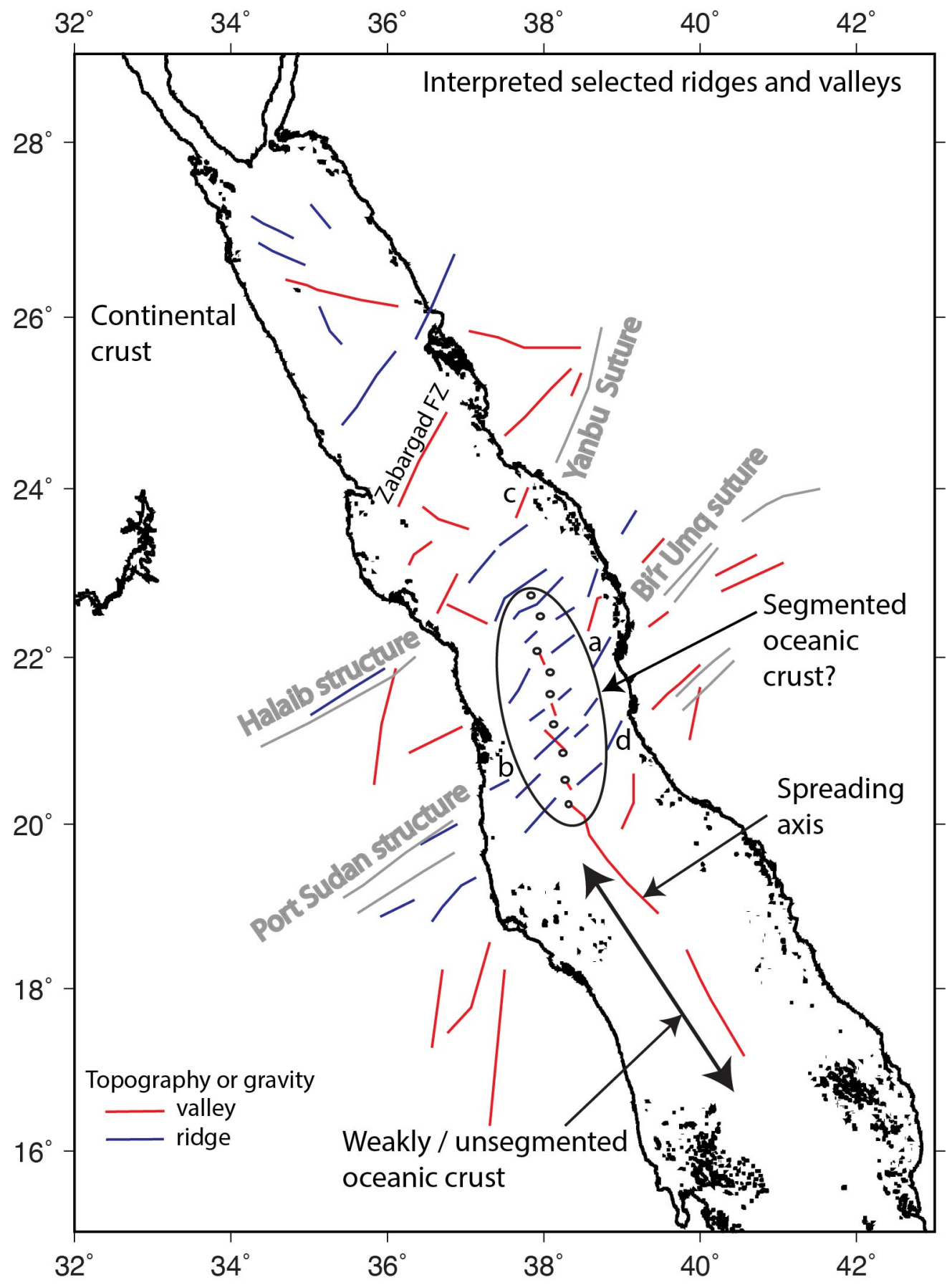

Figure 11. Interpretation of some lineaments from the shaded relief and curvature plots (Figure 7) along with, in grey, the shield structures from Figure 1 (inset). Red lines represent valleys and blue lines ridges in topography and gravity data. Small open circles locate where across-axis gravity lows intersect the spreading axis (from Figure 7c). 
Large ellipse highlights area of oceanic-like spreading segments. Annotation a-d locates some near-shore lineaments discussed in the text.

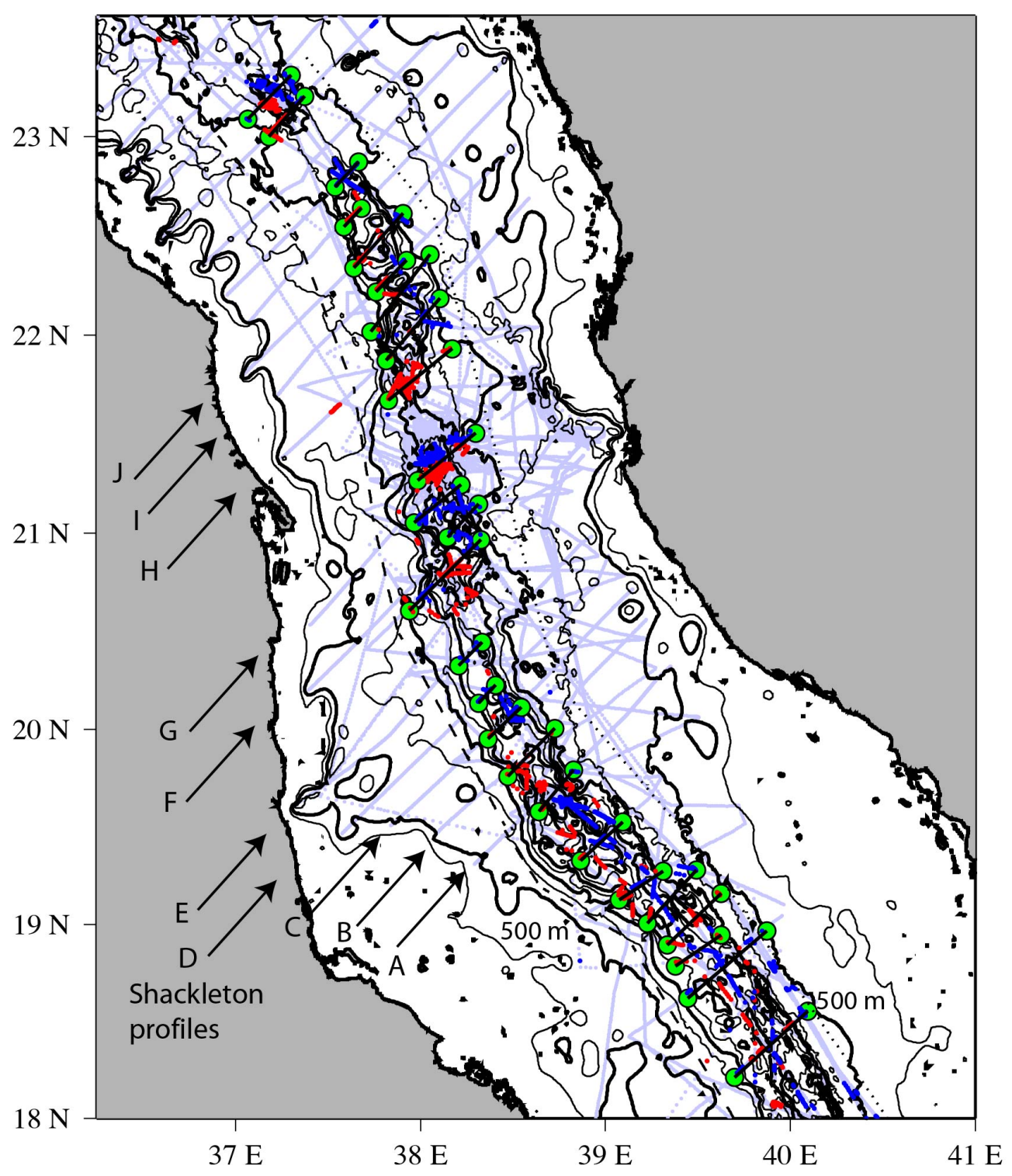

Figure 12. Residual magnetic anomalies with values greater than $300 \mathrm{nT}$ shown in red and less than $-300 \mathrm{nT}$ shown in bold blue. These data were obtained from the National Geophysical Data Center (www.ngdc.noaa.gov/mgg). To reduce effects of reference field errors in the original data reduction, residual anomalies were offset by the mean 
value for each cruise dataset computed over $14^{\circ}-28.5^{\circ}$. Light blue lines show the extent of remaining magnetic anomaly data lying between -300 and +300 nT. Bathymetry contours (every $250 \mathrm{~m}$ with every $500 \mathrm{~m}$ in bold) were derived from the data of Becker et al. (2009). Green-filled circles are interpreted maximum lateral extents of the central 300 nT anomalies. Dotted and dashed lines locate two near-axis bathymetry profiles shown in Figure $10 \mathrm{~b}$ presumed to be on the evaporites. Arrows with letters A-J refer to profiles collected on RRS Shackleton (data shown in Figure 13). 


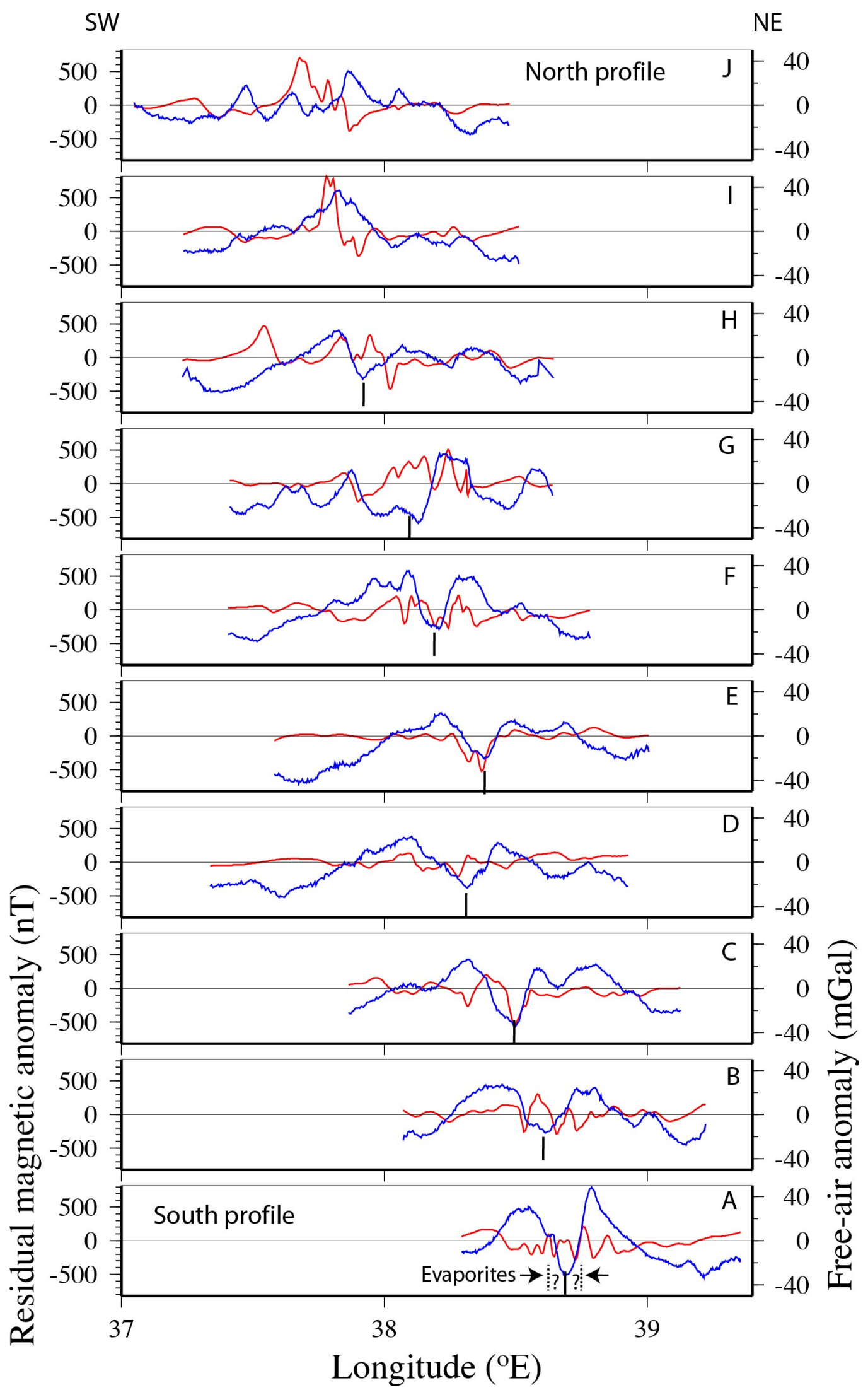


Figure 13. Profiles of magnetic total field (red) and free-air gravity anomaly (blue) collected on RRS Shackleton in 1979 along lines A-J located in Figure 12 showing complexity of the axial anomaly (vertical solid lines are possible spreading axis interpreted from the gravity lows) and smaller amplitude off-axis anomalies. Because of the density contrast at the seabed, the axial gravity anomalies also mimic the axial topographic trough and therefore suggest the likely extent of flowage as shown in profile A (though note the evaporite flow fronts in detail may extend into the axial valley floor as shown in Figure 3). 


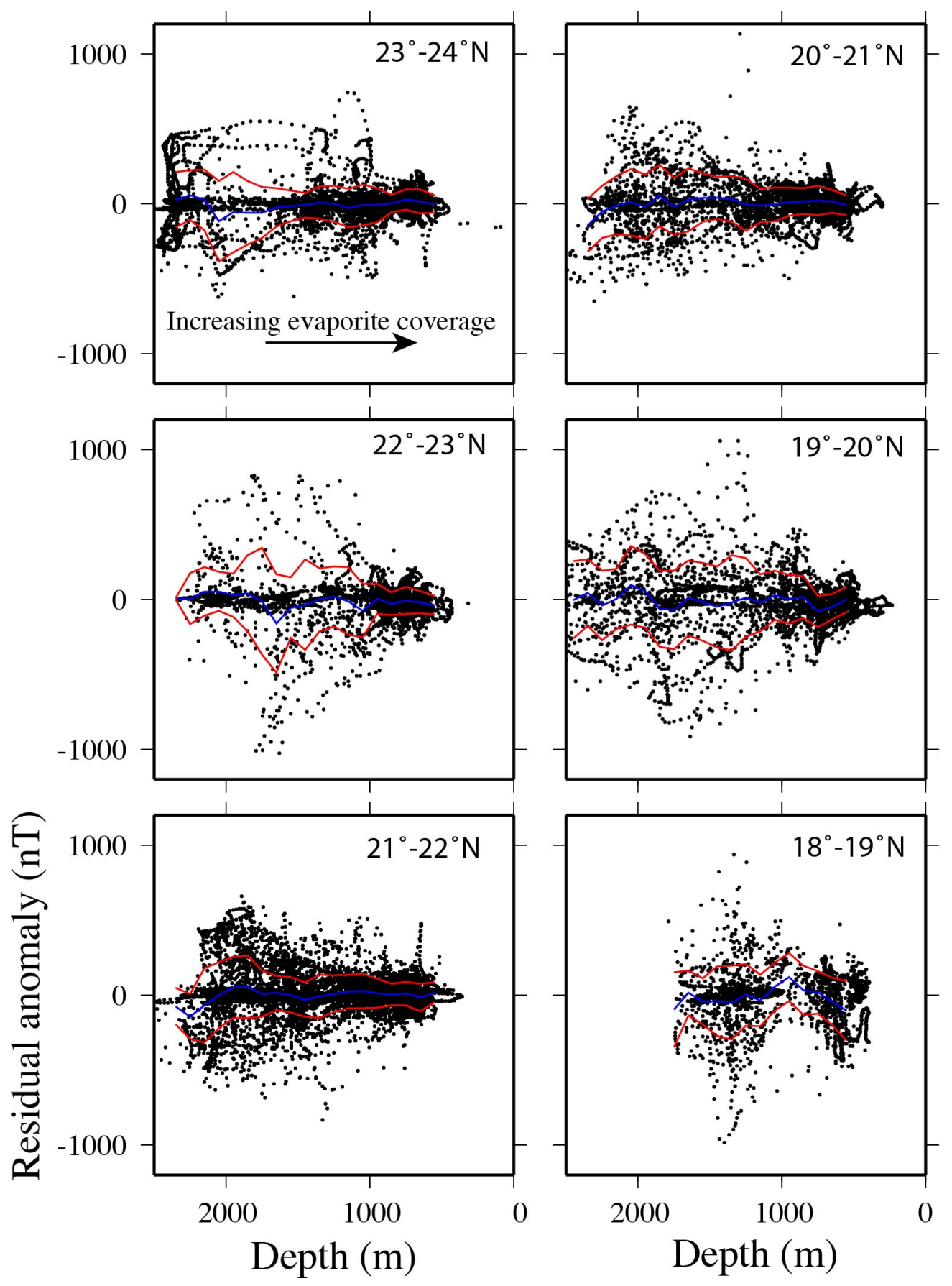

Figure 14. Scatterplots showing the variability in residual magnetic anomaly with depth for a series of latitude ranges (upper-right in each panel). Blue and red lines represent the data mean and standard deviation, respectively, computed in $100 \mathrm{~m}$ intervals. Decreasing variability corresponds roughly with shoaling elevation at the edges of the deeps and hence with the likely occurrence of evaporites. 